NBER WORKING PAPER SERIES

\title{
WHERE DOES ENERGY R\&D COME FROM? EXAMINING CROWDING OUT FROM ENVIRONMENTALLY-FRIENDLY R\&D
}

\author{
David Popp \\ Richard G. Newell \\ Working Paper 15423 \\ http://www.nber.org/papers/w15423
NATIONAL BUREAU OF ECONOMIC RESEARCH
1050 Massachusetts Avenue
Cambridge, MA 02138
October 2009

We thank Neelakshi Medhi for excellent research assistance, and Rebecca Henderson, Iain Cockburn, Nat Keohane, and seminar participants at the 2008 AEA Winter Meetings, 2008 Spring NBER Productivity Meeting and the U.S. Environmental Protection Agency's National Center for Environmental Economics for helpful comments on earlier drafts. This research was supported by the Office of Science (BER), U.S. Department of Energy, Grant No. DE-FG02-04ER63927. The views expressed herein are those of the author(s) and do not necessarily reflect the views of the National Bureau of Economic Research.

NBER working papers are circulated for discussion and comment purposes. They have not been peerreviewed or been subject to the review by the NBER Board of Directors that accompanies official NBER publications.

(C) 2009 by David Popp and Richard G. Newell. All rights reserved. Short sections of text, not to exceed two paragraphs, may be quoted without explicit permission provided that full credit, including $\odot$ notice, is given to the source. 
Where Does Energy R\&D Come From? Examining Crowding Out from Environmentally-Friendly R\&D

David Popp and Richard G. Newell

NBER Working Paper No. 15423

October 2009

JEL No. O33,Q4,Q42,Q55

\begin{abstract}
Recent efforts to endogenize technological change in climate policy models demonstrate the importance of accounting for the opportunity cost of climate $R \& D$ investments. Because the social returns to R\&D investments are typically higher than the social returns to other types of investment, any new climate mitigation $R \& D$ that comes at the expense of other $R \& D$ investment may dampen the overall gains from induced technological change. Unfortunately, there has been little empirical work to guide modelers as to the potential magnitude of such crowding out effects. This paper considers both the private and social opportunity costs of climate R\&D. Addressing private costs, we ask whether an increase in climate $R \& D$ represents new $R \& D$ spending, or whether some (or all) of the additional climate $R \& D$ comes at the expense of other $R \& D$. Addressing social costs, we use patent citations to compare the social value of alternative energy research to other types of $R \& D$ that may be crowded out. Beginning at the industry level, we find some evidence of crowding out in sectors active in energy $R \& D$, but not in sectors that do not perform energy $R \& D$. This suggests that funds for energy $R \& D$ do not come from other sectors, but may come from a redistribution of research funds in sectors that are likely to perform energy R\&D. Given this, we proceed with a detailed look at climate $R \& D$ in two sectors - alternative energy and automotive manufacturing. Linking patent data and financial data by firm, we ask whether an increase in alternative energy patents leads to a decrease in other types of patenting activity. We find crowding out for alternative energy firms, but no evidence of crowding out for automotive firms. Finally, we use patent citation data to compare the social value of alternative energy patents to other patents by these firms. Alternative energy patents are cited more frequently, and by a wider range of other technologies, than other patents by these firms, suggesting that their social value is higher.
\end{abstract}

David Popp

Associate Professor of Public Administration

Syracuse University

The Maxwell School

426 Eggers

Syracuse, NY 13244-1020

and NBER

dcpopp@maxwell.syr.edu

Richard G. Newell

Nicholas School of the Environment

Duke University

Box 90227

Durham, NC 27708

richard.newell@duke.edu 
Throughout the world, proposals to reduce carbon emissions include increased research and development (R\&D) funding (de Coninck et al 2008; Newell 2007). Both a 1997 report from the President's Committee of Advisors on Science and Technology (PCAST) and a 2004 report from the bipartisan National Commission on Energy Policy recommended doubling U.S. government energy R\&D spending. Others advocate increases by a factor of five or ten, likening the need for new energy technologies to the Manhattan Project's efforts to create a nuclear weapon (Kammen \& Nemet, 2005). Such proposals raise two concerns. First, R\&D subsidies will likely have little effect unless accompanied by policies requiring significant emissions reductions. Second, dramatic increases in energy $R \& D$ may come at a high cost, as these research efforts may draw away research funding and scientists from other productive sectors (Popp, 2006a, Yang \& Oppenheimer, 2007, Schneider \& Goulder, 1997). This paper focuses on the second of these concerns, by asking whether new energy R\&D efforts crowd out other types of R\&D spending.

Recent efforts to endogenize technological change in Integrated Assessment (IA) models of climate policy highlight the need to properly account for the opportunity cost of environmental $R \& D$ investments. Because the social returns to $R \& D$ investments are typically higher than the social returns to other types of investment, any new environmental $R \& D$ that comes at the expense of other $R \& D$ investment will dampen the cost-savings potential of induced technological change. Popp (2004) shows that assumptions about the magnitude of such crowding out explain much of the variation in results across IA models with induced technological change. For example, among models that use R\&D expenditures as the means by which technology improves, Nordhaus (2002) assumes a fixed supply of R\&D labor, so that new energy $R \& D$ completely crowds out other $R \& D$. As a result, he finds induced technological 
change has little effect on welfare or climate policy. In contrast, Buonanno et al. (2003) model energy R\&D and other R\&D as complements, so that crowding out does not occur. Their model finds a stronger effect for policy-induced R\&D than other models.

Note that the question of crowding out is even more important for IA models than it is for energy R\&D policy. In many IA models, such as those cited above, overall technological change is treated as exogenous. While crowding out may be observed in the data, so that other R\&D falls when energy R\&D increases, this may simply be a result of rational, profit maximizing firms switching R\&D resources from opportunities that become less profitable as energy prices increase (e.g. designing larger, gas-guzzling vehicles) to opportunities that are more profitable (e.g. designing hybrid vehicles). In such a case, one might not be concerned about crowding out from the perspective of a policy maker increasing spending on energy R\&D - in fact, such crowding out may be a desired policy effect. However, in terms of these models, whether or not it is profitable to reduce $R \& D$ on other projects is irrelevant. Since energy $R \& D$ is endogenous in these models, but other $R \& D$ is not, $R \& D$ resources switched from non-energy to energy projects will be double-counted unless the reduction in non-energy R\&D is accounted for by reducing the level of autonomous technological change when more energy R\&D is induced. That is, exogenous levels of autonomous technological change in these models should only include the effects of non-energy $R \& D$. If energy $R \& D$ replaces other forms of $R \& D$, the effects of autonomous technological change must fall.

Unfortunately, there has been little empirical work addressing the potential magnitude of such crowding out effects. Related work includes Link (1982), who finds evidence that part of the measured decline in productivity $R \& D$ in the 1970 s occurred because more $R \& D$ was directed towards environmental research, whose benefits (e.g. a cleaner environment) were not 
measured in traditional market outcomes. Using macroeconomic data, Nemet and Kamen (2007) find little evidence of crowding out from federal energy R\&D spending. However, in a survey of Austrian firms, Roediger-Schluga (2003) finds most firms cancelled or postponed other R\&D projects in order to increase environmental R\&D after passage of new volatile organic compound standards. ${ }^{1}$ This paper addresses the crowding out issue directly, focusing on both the private and social opportunity costs of climate $R \& D$. Here, the key question is whether increases in energy $R \& D$ are likely to represent new $R \& D$ spending, or whether some (or all) of the additional climate $R \& D$ comes at the expense of, or crowds out, other R\&D. To address the social opportunity costs of climate $R \& D$, we ask whether the social value of energy $R \& D$ differs from other types of innovation. The paper also contributes to the literature on energy R\&D by providing a detailed description of who performs this R\&D.

We explore the question of private $R \& D$ opportunity costs at several levels. First, we examine the effect of economy-wide increases in energy $R \& D$ on total $R \& D$ spending at the industry level in order to investigate whether investment dollars flowing to energy-related research are coming at the expense of overall $R \& D$ in specific sectors. While this first question addresses flows across sectors, it does not tell us whether and how research activity changes within individual firms as energy R\&D activities increase. To address this second question, we use patent data to examine changes in the research portfolios of companies actively performing energy R\&D. New climate R\&D undertaken by firms will crowd out other R\&D if firms are financially constrained. Several papers have examined factors determining firm-level R\&D financing and conclude that financial constraints are often present. These results vary by country (e.g., financial constraints appear more binding in the U.S. and U.K. than in France and

\footnotetext{
${ }^{1}$ In a related vein, several authors have asked whether increases in defense R\&D spending crowds out other R\&D. Examples include Morales-Ramos (2002), Buck et al. (1993), and Mueller and Atesoglu (1993).
} 
Germany) and by firm size (financial constraints are more binding for smaller firms). ${ }^{2}$ Moreover, Lach \& Schankerman (1988) show that firms tend to smooth R\&D investment over time, suggesting that there are large adjustment costs to changing the level of R\&D within a firm. However, such studies have typically used aggregate industry or firm-level R\&D data. Thus, they are unable to distinguish between types of $R \& D$ performed. In this paper, we combine firm-level financial data taken from the Compustat database of publicly traded firms, with patent records for the same firms. We use patent classifications to separately identify the results of energy research projects from other research. Using these data, we can investigate whether increases in energy patents crowd out other patenting activity at the firm level.

As we find some evidence of crowding out within sectors, we conclude by considering the social value of research by energy firms. Using patent citation data as a measure of the social value of innovations, we ask whether energy patents are more valuable than other innovations. While we do find evidence that energy R\&D patents are more valuable, they do not appear to be more valuable than the patents most likely to be crowded out by an increase in energy R\&D.

\section{Crowding Out Across Sectors}

We begin by looking at the effect of energy R\&D spending on overall R\&D activity at the sectoral level. Here, we are interested in whether R\&D flows across sectors when energy $R \& D$ levels change, so that there is a net draw on $R \& D$ away from specific sectors. For this, we use R\&D data from the National Science Foundation Survey of Industrial Research and Development. Defining $I R D_{i, t}$ as company-financed R\&D performed in industry $i$ at time $t, E R D_{t}$

\footnotetext{
${ }^{2}$ Recent papers on R\&D financing constraints include Hall et al. (1999), who find stronger financial constraints in the U.S. than in Japan and France; Harhoff (1998), who finds weaker constraints in Germany, with smaller firms most affected; and Bougheas, Görg, \& Strobl (2003), who find evidence of financial constraints in Irish firms. Hall (2002) provides a review of this literature on firm-level financing of $R \& D$.
} 
as the level of total company-financed energy R\&D spending in year $t, F E D R D_{t}$ as federallyfunded R\&D performed by industry, ${ }^{3}$ and $Y_{i, t}$ as value added in industry $i$ at time $t$, we propose the following relationship:

$$
I R D_{i, t}=f\left(I R D_{i, t-1}, Y_{i, t-1}, F E D R D_{t-1}, E R D_{t}\right)
$$

We include the lagged dependent variable to allow for gradual adjustment of R\&D in response to changing conditions. Standard errors are corrected for both autocorrelation and heteroskedasticity.

In this equation, energy $R \& D$ is endogenous, as both it and total sectoral-level $R \& D$ are influenced by factors such as energy prices. Lagged industry-performed R\&D is also endogenous. Thus, we use an instrumental variables approach, using lagged values of the other independent variables, total company-financed energy $R \& D$ spending in year $t-2\left(E R D_{t-2}\right)$, the price of energy, ${ }^{4}$ gross domestic product, defense spending, and lagged federal energy $R \& D$ spending as instruments. ${ }^{5}$

One limitation to the above analysis is that industry-level energy $R \& D$ data are not available for all industries. Although published energy R\&D data include industry-level breakdowns, there are many missing observations in these data. This is particularly true in industries that do not perform much energy $R \& D$. Thus, in this regression we are only able to include economy-wide energy R\&D financed and performed by industry. This allows us to focus on crowding out across sectors. That is, as the total level of energy R\&D spending goes

\footnotetext{
${ }^{3}$ Unfortunately, there are several missing observations in the industry-level data for federally-funded R\&D performed by industry, so that we can only include aggregate levels of government-funded R\&D.

${ }^{4}$ Energy price data come from the US Energy Information Administration, and are the consumption-weighted average price for primary energy and retail electricity in the four end-use sectors (residential, commercial, industrial, and transportation).

${ }^{5}$ Because of the large share of R\&D spending that goes to defense, particularly during the 1980s, Lichtenberg (1987) finds a negative relationship between defense spending and the share of R\&D going to energy. Based on this, we include defense R\&D as an instrumental variable.
} 
up, do R\&D resources flow from non-energy sectors to those doing more energy R\&D? Figure 1 shows the trends in this variable, for both company-financed and federal-government financed energy R\&D performed by industry.

Our strategy for identifying crowding out across industries is to see how changes in the overall level of energy R\&D spending affect company R\&D performance at the industry-level. However, because we have total industry-level R\&D on the left-hand side, but economy-wide energy $R \& D$ on the right-hand side, our dependent variable includes energy R\&D financed by that industry. Since our dependent variable will, in some cases, include energy R\&D for that industry, careful interpretation of the coefficient on overall energy R\&D is needed. A coefficient of 0 suggests that $\mathrm{R} \& \mathrm{D}$ in that industry is not affected by increases in overall energy $\mathrm{R} \& \mathrm{D}$. Whether no effect on total industry-level R\&D should be considered crowding out depends on the ex ante level of energy R\&D in the industry. In industries that perform a significant amount of energy R\&D, finding no increase in industry-wide R\&D when energy R\&D increases suggests the industry has cut back on other types of R\&D. However, a coefficient of 0 in an industry that does not perform energy $R \& D$, such as the food industry, suggests that crowding out is not a problem. For these industries, we would be concerned about crowding out only if the coefficient on energy R\&D was negative - implying that an economy-wide increase in energy R\&D took R\&D resources away from this industry.

Thus, we divide our sample of industries into two groups. We begin by looking at the percentage of $R \& D$ devoted to energy $R \& D$ in years for which data are available. We then separately consider industries for which spent, on average, $5 \%$ or more of total $\mathrm{R} \& \mathrm{D}$ expenditures on energy R\&D and those which spent less than $5 \%$ on energy R\&D. ${ }^{6}$ Because of

\footnotetext{
${ }^{6}$ For sensitivity analysis, we also present results using cutoffs of $1 \%$ and $10 \%$ for energy-R\&D intensive industries.
} 
data availability, we look at two samples. Using data from 1983-1997, we are able to include 16 industries. However, this does not allow us to look at crowding out during the energy crisis of the 1970s, when energy R\&D levels were highest. Thus, we also look at a subsample of 7 industries that have data available from 1973-1997. Tables 1 and 2 list the industries in the larger and smaller samples, respectively, along with descriptive data on the key industry variables. The tables also show the average percentage of $R \& D$ devoted to energy within each sector, for the years in which industry-level detail is available. In each table, the industries are sorted by this percentage. Finally, note that the last two lines of each table present summary statistics for all industries with more than or less than five percent of R\&D devoted to energy. In both samples, energy intensive industries are larger. These include industries such as petroleum refining and transportation equipment.

We start with the results for the larger sample, which begins in 1983. Table 3 presents these results. Panel A presents results for our preferred model. The first two columns present results for industries that perform little energy R\&D. Here, we see no evidence of crowding out. The insignificant coefficient on economy-wide private energy R\&D spending suggests that increases in energy $R \& D$ elsewhere in the economy have no effect on overall $R \& D$ spending in these specific industries. This result holds using either a $1 \%$ or $5 \%$ cut-off for energy-R\&D intensive industries. Thus, we find that increases in energy R\&D spending do not appear to crowd out R\&D in unrelated sectors.

Results for other variables are generally as expected. The model suggests that R\&D adjusts gradually, as the coefficient on lagged company R\&D spending is significant and close to 1. Industry value added increases $R \& D$, although the magnitude of this effect is small. Note from Table 1 that several of the industries in the low energy R\&D group are industries with low 
overall R\&D intensities, which might explain this low magnitude. Finally, the negative sign on federal R\&D suggests crowding out from government $R \& D$, although this coefficient is insignificant for low energy R\&D industries.

For industries that spend $5 \%$ or more of their R\&D budget on energy $R \& D$, the results are similar, but the interpretation is different. In columns 3 and 4, we see a coefficient on energy R\&D that is not statistically different from zero. Since these are industries that perform energy $R \& D$, the null hypothesis of no crowding out would be that the coefficient on energy $R \& D$ equals 1 . That is, every dollar spent on energy R\&D should be new spending, so that total $R \& D$ in the industry increases. That null hypothesis is clearly rejected in all cases, suggesting crowding out within those sectors that perform energy R\&D. As before, the coefficients on other variables appear reasonable. Of particular interest here is the coefficient on value added of about 0.02. This is consistent with the fact that just over two percent of GDP is devoted to energy R\&D. We also see evidence for a small crowding out effect from federal R\&D that is now statistically significant.

One concern is the negative coefficient on energy R\&D in column 4 . One issue may be endogeneity, particularly if other shocks to the economy, such as higher energy prices, affect industry value added. To address this, we remove one outlier industry: petroleum refining and extraction. Over $50 \%$ of R\&D goes to energy in this sector, compared to $9 \%$ in the next highest sector. Without petroleum, the results are similar, but the coefficient on energy R\&D is now positive. Still, we can reject the null hypothesis that this coefficient equals 1 , suggesting some crowding out in these industries.

A second potential concern with these results is that we have a weak instruments problem. While our instruments our valid, as suggested by the high $p$-values for Hansen's $J$ - 
statistic (Baum et al. 2007), the Wald F statistic based on the Kleibergen-Paap rk statistic is less than the "rule of thumb" of 10, suggesting weak instruments (Staiger and Stock, 1997; Baum et al., 2007). This results from the poor fit between our instruments and the lagged dependent variable. For each regression, the $F$-stat for the first-stage regression of the lagged dependent variable is less than 10 , whereas the $F$-stat for the first-stage regression of the energy $R \& D$ variable is consistently much larger than 10 . To address this, panel B of Table 3 presents an alternative estimation strategy, in which the three-year lag of the dependent variable is also used as an instrument. While one might expect the three-year lag to be endogenous, particularly if adjustment is gradual, Hansen’s $J$-statistic still confirms the validity of our selected instruments. Moreover, for three of our specifications, the Wald $F$ statistic based on the Kleibergen-Paap rk statistic is now greater than 10, and we reject the null hypothesis that the model is underidentified, at least at the 10 percent level, for each specification. Most importantly, the main results do not change. We still see no evidence of crowding out in low energy R\&D industries, and evidence suggestive of crowding out in high-energy R\&D industries.

Turning in Table 4 to the sample of 7 industries with data from 1973-1998, we find similar results. Because of the larger amount of energy R\&D performed during the 1970s, here we use $5 \%$ and $10 \%$ as cutoffs for energy R\&D intensity, as none of the industries in this sample spend less than one percent of R\&D on energy research. Once again, in low energy $R \& D$ industries, there is no measurable crowding out effect: Moreover, the value of other coefficients, such as value added, is also consistent with expectations. In high energy R\&D industries, we again get a negative effect on total energy R\&D. Here, omitting petroleum extraction and refining does not change the result. Also as before, the results do not change when the three-year lag of the dependent variable is used as an additional instrument. 
The results of these regressions suggest that, during past spikes in energy research activity, research funding did not flow from non-energy R\&D sectors to sectors performing R\&D. While the results raise the possibility of crowding out within these energy R\&D sectors that is, that new energy $R \& D$ in these sectors comes at the expense of other $R \& D$ in these sectors, these results appear less certain. For example, the conclusions about crowding out in these sectors do not change as the cutoff used to define high energy R\&D sectors changes. This poses problems for interpretation. Consider the chemical industry, which spends $3.2 \%$ of its $\mathrm{R} \& \mathrm{D}$ on energy-related research. Using the one percent cutoff in table 3 would suggest that the chemical industry experiences crowding out when energy research increases. However, using a five percent cutoff would suggest that it does not.

A final concern with the regressions for high energy R\&D industries is that all energy R\&D spending does not go to a single industry. For example, if one new dollar of energy R\&D is equally shared among four industries, the appropriate test for crowding out would be whether the coefficient on energy R\&D equals 0.25 . Using the average share of energy R\&D assigned to industry $i$ for years for which industry-level energy R\&D data are available, we find that this ranges from $1.5 \%$ for primary metals to $27 \%$ for petroleum refining. Thus, while we reject the null hypothesis that the coefficient on energy R\&D is 1 in these models, in most cases we cannot reject the null hypothesis that the coefficient is 0.27 - that is, that $27 \%$ of the total energy $R \& D$ is going to industry $i$.

Given this concern, Table 5 presents one additional set of regressions for high-energy R\&D industries. Here, we replace the economy-wide level of energy R\&D with an estimated value for each industry, found by multiplying the economy-wide energy $R \& D$ data by the average share of energy R\&D going to that industry from years in which industry-specific data 
are available. These results are suggestive of crowding out, but are very imprecise. ${ }^{7}$ Here, the null hypothesis of no crowding out again implies that the coefficient on energy R\&D be one that all new energy R\&D is new R\&D. Except for the 1983-1997 data without refineries, we reject this null hypothesis. However, the negative signs on these coefficients are troubling (although not significant), as are the large magnitudes. At best, we can only say that the results for industries that perform energy $\mathrm{R} \& \mathrm{D}$ are ambiguous, and await better data. Given this ambiguity, we turn next to firm-level patent data, to take a closer look at the changes occurring within firms as energy R\&D increases.

\section{Crowding Out Within Sectors}

To address the question of crowding out within sectors, we look at the research decisions made by individual firms. In principle, we would like to know if increases in energy $R \& D$ at the firm level crowd out other types of R\&D. Unfortunately, R\&D data are not available at the firm level with this level of detail. Instead, we use patents as a proxy for energy and other R\&D. ${ }^{8}$ Using patent data, we classify firm research outcomes as energy-related or not. We then ask whether increases in energy-related research lead to decreases in other research.

Our model specification is purposely sparse. Define $O P A T_{i, t}$ as non-energy patents assigned to firm $i$, with an application year of $t$. Similarly, EPAT $T_{i, t}$ represents energy patents from these same firms. $\mathbf{X}_{\mathbf{i}, \mathbf{t}}$ represents a vector of firm-specific control variables, such as capital, sales, or debt, to control for firm size. We estimate an equation of the form:

\footnotetext{
${ }^{7}$ Table 5 is equivalent to panel A of Tables 3 and 4 . Results do not change when using $R \& D_{i, t-3}$ as an instrument, except for the case without refineries between 1973-1997. However, for that case, Hansen's $J$ test shows that the instruments are invalid. Results are available from the authors upon request.

${ }^{8}$ Griliches (1990) shows that patents, sorted by their year of application, are strongly correlated with R\&D expenditures, and thus make a good proxy for R\&D spending. For a discussion of other applications of patent data in environmental economics, see Popp (2005).
} 


$$
O P A T_{i, t}=f\left(O P A T_{i, t-1}, E P A T_{i, t}, \mathbf{X}_{\mathbf{i}, t}, a_{i}, b_{t}\right)
$$

where $a_{i}$ and $b_{t}$ represent firm and year fixed-effects. Note that because we are using patents as a proxy for R\&D spending, we do not include R\&D spending as a control variable. While one would expect increases in R\&D to increase patenting activity, it does not allow us to determine whether one type of R\&D has replaced the other. We include year effects to allow for changes in patent policy that change the propensity to patent among all inventors, and to control for truncation problems in the last years of our data. Because not all patent applications are made public, we obtain the application years of our patents from the final granted patent publication. We have data on patents granted through 2002. Since some patent applications filed in the late 1990s and early 2000s would still have been pending in 2002, counts of patent applications in these years will be too low. As such, we restrict our analysis to patent applications filed between 1970 and 1999. Year dummies correct for any remaining truncation problem.

\section{A. Data}

We examine data for two types of energy innovations. First, we look at patents aimed at new energy technologies. These include renewable technologies such as wind and solar power, as well as new sources that may use fossil fuels, such as fuel cells and coal liquefaction. This sample includes firms from a broad cross-section of industries. To focus more closely on a specific industry, we also look at new technologies in the automotive sector. Here, we include fuel cells and hybrid vehicles, as well as innovations designed to improve the fuel economy of internal combustion engines.

Our patent data comes from two sources. First, we identify relevant energy patents using the Delphion patent database, using a combination of patent classification codes and, in the case 
of energy efficiency patents, appropriate keywords. ${ }^{9}$ Appendix A shows the technologies included in our paper, along with the relevant search strategies for each. To identify all patents granted to firms working in these fields, we use the NBER patent database (Hall, Jaffe, \& Trajtenberg, 2001). Based on the firm information available in the NBER database, this leaves us with a sample of patents granted from 1971-2002. ${ }^{10}$

From this, we calculated the total number of patents granted to each firm in our sample, along with the number of energy patents. We eliminated firms where nearly all patents are energy patents, such as International Fuel Cells or Ballard Power Systems (a fuel cell manufacturer). ${ }^{11}$ We also eliminated firms with less than $1.5 \%$ of their patents in one of our energy categories. This eliminates large, diversified firms such as General Electric and some chemical companies. In both cases, the percentage of energy patents is so small that one would not expect to identify any reasonable relationship between energy and other patents. For the remaining firms, we searched Compustat to identify firm-specific variables. Our firm-specific variables, all measured in billions of 2000 dollars, are capital (Compustat item \#8: Property, Plant, and Equipment - Total (Net)), net sales (Compustat item \#18), and debt (Compustat item \#9). Using only firms with greater than $1.5 \%$ of their patents in either technology area, this leaves us with a sample of 13 firms for automotive technology and 31 firms for alternative energy. Table 6 displays, by firm, average values for each of the variables in our dataset.

To get a sense of who patents in these technology areas, Tables 7 and 8 present the top patent assignees by field. Table 7 lists the top 20 assignees for each field. Note that these two

\footnotetext{
${ }^{9}$ Available at www.delphion.com.

${ }^{10}$ The NBER database limits us to patents granted from 1968, as firm identifiers are not available before that date. Similarly, the NBER data currently ends in 2002. However, we only use patents granted from 1971 because the Delphion database only includes abstracts for keyword searching on patents beginning in 1971.

${ }^{11}$ Our initial cutoff for this was firms with more than $2 / 3$ of their patents pertaining to energy. However, once we search for financial data on the remaining firms, no firm with more than $29 \%$ of their patents pertaining to energy remain in the dataset.
} 
lists are dominated by large firms with just a few percent of their total patents falling in these categories. Only a few predominately energy companies, such as Ballard Power Systems and International Fuel Cells Corporation, appear in the top 20. For each technology area, Table 8 lists the top 20 firms having the greatest percentage of their patents falling in one of these categories. Here, we only include firms with 10 or more patents in these areas, as there are hundreds of firms that have only one relevant energy patent and no other patents. There are many companies specializing in the alternative energy field, as relevant energy patents comprise $70 \%$ or more of the total patent portfolio for each of the firms in the top 20 . In contrast, the top 20 automotive energy firms include companies for which energy patents comprise just 16\% or more of their patent portfolio.

In both cases, the distribution of assignees is highly skewed. Not counting patents assigned to individuals, there are 3,059 unique patent assignees in the alternative energy field. Of these, 1,935 have just one alternative energy patent. Only $17 \%$ of alternative energy patents are assigned to the top 20 assignees (not counting individually assigned patents). There are 18,107 total patents in this field. The companies included in our regression have 2,011 of these, or 11 percent. For these 32 firms, energy patents represent 3.6 percent of their total patenting activity. For automotive technologies, there are 1,438 unique patent assignees for 9,895 total patents. Of these, 813 have just one automotive energy patent. Larger firms play a more important role here, as 32 percent of patents are assigned to the top 20 assignees (again, not counting individually assigned patents). The companies included in our regression have 1,269 of these, or 13 percent. Energy patents represent 3.9 percent of total patenting activity for these 14 firms.

Finally, Figures 2 and 3 show energy and non-energy patents for the firms in our alternative energy and automotive energy regressions, respectively. In each, patents are sorted 
by the year of application. The number of energy patent applications per year is on the left $y$ axis, and the number of non-energy patent applications per year is on the right $y$ - axis. Note that alternative energy patents increase during the energy crises of the 1970s. Afterwards, energy patents decline, and non-energy patents increase, suggesting possible crowding out. For automotive energy patents, the bulk of applications occur more recently, as a result of research on fuel cell and hybrid vehicles. Until this recent spike, both energy and non-energy patents tended to move together. The figure suggests crowding out may occur at the end of the sample.

\section{B. Results}

Tables 9 through 12 present results for alternative energy patents and automotive energy patents, respectively. In each case, the null hypothesis is that energy patents do not crowd out other patents, which we fail to reject unless the coefficient on energy patents is significantly different from zero. Tables 9 and 11 include six specifications - three including year dummies, and three that replace the year dummies with a time trend. Using the time trend provides additional degrees of freedom, and allows us to use energy prices as an additional instrument for energy patents. However, the trend may fail to capture discrete changes in patent policy, nor any remaining truncation bias in our data. To allow for the possibility of gradual adjustments, we present specifications with a lagged dependent variable. In these models, both the lagged dependent variable and energy patents are endogenous. We use the first two lagged values of the exogenous dependent variables (sales, debt, and capital, as well as the time dummies or trend) as instruments, along with second-year lagged values of energy patents. In addition, we use current and lagged energy prices as instruments in the model using a time trend. Tables 10 and 12 present additional sensitivity analysis to assess the validity of our instruments. All regressions 
use GMM estimation with firm fixed effects. Standard errors are corrected for both autocorrelation and heteroskedasticity.

We look first at the results for alternative energy technologies. The first three columns of Table 9 present results of the model with year dummies, and the last three present results of the model with a time trend. The evidence for crowding out is mixed. In each model, the coefficient on energy patents is negative, and slightly larger than 1, suggesting that a new energy patent fully crowds out a non-energy patent. However, these coefficients are only significant in column (1), which uses year dummies and a full set of controls. As expected the effect of sales is positive, but is not significant in the model including capital and debt. ${ }^{12}$ The effect of capital and debt is insignificant. Lagged other patents has a positive coefficient less than one, suggesting a gradual adjustment process.

The positive effect of sales on patenting is also suggestive of crowding out. Crowding out is most likely to occur when firms face financial constraints, so that they are unable to take advantage of all profitable research opportunities. In the existing literature on R\&D financing, tests of financial constraints are indirect (see, for example, Hall 2002). Intuition about these tests can be gained by considering what firms choose to do with new cash flow. If firms choose to invest new cash flow in additional $R \& D$, this suggests that the firm faced research opportunities that it had not taken advantage of due to financial constraints. That increased revenues from sales leads to more patenting suggests that these alternative energy firms may face $R \& D$ financing constraints. ${ }^{13}$

\footnotetext{
${ }^{12}$ The model uses lagged sales, on the assumption that increased revenues from new sales are used to fund R\&D in the following year.

${ }^{13}$ We choose not to overemphasize this result, as the ideal measure of cash flow would be net profits. In results not reported here, we found net profits to consistently have an insignificant effect on other patenting. As these results also magnify the weak instruments problem noted below, we omit profits from the models in this paper.
} 
Unfortunately, regression diagnostics suggest that our instrumental variables may not be sufficient. The fit of the model is generally good, with $R^{2}$ statistics near 0.6. As shown by the $p$ value from Hansen's $J$ statistic presented below the estimates, we cannot reject the null hypothesis that the instruments are valid. However, the Wald $F$ statistic based on the Kleibergen-Paap rk statistic is less than the "rule of thumb" of 10, suggesting weak instruments (Staiger and Stock, 1997; Baum et al., 2007).

Further exploration suggests that the weak instruments problem comes from the lagged dependent variable. For instance, in column (1), the F-statistic for the first-stage equation for lagged other patents is just 2.69, where as it is 13.03 for the first-stage equation for energy patents. Given this, Table 10 shows results from two additional specifications. ${ }^{14}$ First, in columns (2) and (5) we use 3-year lagged Other Patents as an additional instrument. While one might expect this to be endogenous, particularly if the adjustment process is slow, we still do not reject the null hypothesis that the instruments are valid using Hansen's $J$-statistic. As would be expected, the F-statistic for our instruments now improves substantially. Most importantly, this does not change our crowding out result, which is still significant when using a complete set of year dummies. The magnitude of the adjustment parameter falls slightly, but is still significant. Moreover, with better instruments, the effect of sales is now significant in both columns (2) and (5). Finally, columns (3) and (6) present results of a model that excludes the lagged dependent variable. As expected, the F-statistic now suggests that our instruments for energy patents are sufficient. However, our estimates are slightly less precise, and the $R^{2}$ statistics are much lower without the lagged dependent variable. Moreover, while the coefficient on energy patents is still

\footnotetext{
${ }^{14}$ To conserve space, we focus on the model with all three controls for firm characteristics.
} 
negative, it is now insignificant. Given the strong significance of the lagged dependent variable, dropping it from the model provides unsatisfactory results.

The results for automotive energy technologies (Table 11) are less satisfying. As noted in the previous section, there are fewer firms in this dataset, leaving us with only 254 observations, compared to 608 for the alternative energy regressions. As a result, although the signs of our estimated coefficients are as expected, only capital is statistically significant at even the 10 percent level. $^{15}$ As before, we have a weak instruments problem. Moreover, the Kleibergen-Paap rk statistic (2006) suggests that the model is unidentified except when sales are the only dependent variable. As shown in Table 12, using the three-year lag of the dependent variable partially addresses the weak instruments problem, although the F-statistic for the instruments is still less than 10. However, the improved fit of the first stage regressions results in statistical significance for both capital and the lagged dependent variable. As before, dropping the lagged dependent variable completely leads to less satisfactory results. Overall, crowding out seems to be less of a problem for the automotive industry. While this may be due to the larger size of these firms, given our smaller sample size, we have less confidence in this result than for our results using alternative energy patents.

\section{What is Crowded Out?}

Given the evidence of crowding out from alternative energy innovations, we take a closer look at innovations in a subset of our sample to see what might be lost when alternative energy innovation increases. To be able to categorize these other patents in greater detail, we limit our

\footnotetext{
${ }^{15}$ Following the discussion of financial constraints above, it is somewhat comforting that both energy patents and sales have no effect on other patents. Also, the automotive firms in our sample are larger than the alternative energy firms, with an average value of capital two billion dollars higher, and average assets that are more than double those of the alternative energy firms. One would expect larger firms to be less likely to face financial constraints, and thus less likely to suffer from crowding out of R\&D resources.
} 
focus to the 12 firms from our alternative energy sample that are energy refinery companies. ${ }^{16}$ Using patent classifications, we categorize all of the patents from these 12 firms into one of 7 technology groups: alternative energy, coal-based fuels, environmental, refining, chemistry, drilling wells, and other technologies. Alternative energy patents include traditional renewable sources such as wind, solar, and geothermal. Coal-based fuels include coal gasification and coal liquefaction patents. In the regression analysis of the previous section, both of these are categorized as alternative energy patents. Among the refineries, these coal-based fuels are an important component of alternative energy innovation, comprising two-third of the alternative energy patents for these firms. Thus, we consider these separately from other alternative energy patents. Environmental patents pertain to pollution control, and include techniques for cleaning up oil spills, as well as isomerization refining techniques developed as part of the phase-out of lead from gasoline and reformulated fuels. Appendix B presents a complete list of the patent classifications in each technology group. Figure 4 shows trends in these seven groups over time.

Table 13 shows the correlation between patent applications per year in each category. ${ }^{17}$ Because overall patent counts move together over time (for instance, as a result of changing firm revenues), we look at both correlations between counts of patents in each group, as well as correlations between the percentage of each year's patents belonging to each group. Using raw patent counts, all correlations are positive. However, the two smallest correlations are between alternative energy and refining, and coal-based fuels and refining. The correlations between either alternative fuels or coal-based fuels and environmental patents are also small. Using correlations between the percentage of patents in each category per year, we now see several negative correlations. This is expected, since the sum of percentages in each year must sum to

\footnotetext{
${ }^{16}$ These firms are Amoco, Atlantic Richfield, Chevron, Conoco, ExxonMobil, Gulf, Kerr-McGee, Mobil, Occidental, Standard Oil, Texaco, and Tosco.

${ }^{17}$ We use patents from 1973-1999, as these are the years appearing in the regression analysis.
} 
100. Here, the correlation between alternative energy patents and refining patents is strongly negative, at -0.70 . The same holds true for the correlation between coal-based fuels and refining. The correlation between alternative energy and pollution control innovations is also negative, but its magnitude is much smaller, at -0.39 . Finally, to focus on the period where crowding out is most likely, panels C and D of Table 13 repeat the analysis for only those patents from 19731987. As shown in Figure 4, this covers the period in which alternative energy innovation increased and then returned to pre-energy crisis levels. While refinery patents still are most likely to be crowded out, we also see evidence of crowding out for patents pertaining to drilling wells. The correlation between the number of alternative energy patents and wells patents is 0.30, and the correlation between the percentages of these patents is -0.65 . While only suggestive, these correlations provide evidence that much of what is crowded out from increased alternative energy research are innovations on refining and drilling wells, both of which would increase production of fossil fuels. Thus, while it is important for such crowding out to be accounted for in integrated assessment models, these results also suggest that one effect of policies designed to increase alternative energy $R \& D$ is to lower incentives for $R \& D$ on traditional fossil fuel energy sources.

\section{The Social Value of Energy Innovations}

While the analysis of the preceding section provides some evidence as to the types of research that are crowded out, it does not tell us anything about the social value of this research. Economists consistently find that the social returns to research are higher than a firm's private returns. ${ }^{18}$ This deviation results from knowledge spillovers due to the public-good nature of new

\footnotetext{
${ }^{18}$ See, for example, Mansfield (1977, 1996), Pakes (1985), Jaffe (1986), Hall (1996), and Jones and Williams (1998).
} 
knowledge. A successful innovator will capture some rewards, but those rewards will always be only a fraction — and sometimes a very small fraction—of the overall benefits to society of the innovation. Hence innovation creates positive externalities in the form of knowledge spillovers for other firms and consumers.

If the social returns to new alternative energy $R \& D$ are no different from the social returns to the $R \& D$ that is crowded out, then simply measuring the magnitude of crowding out is sufficient. However, if these social returns differ, the ultimate economic effect of crowding out will be miscalculated unless these differences are accounted for. A priori, there are two reasons to expect that alternative energy research may have a greater social value than other research. First, comparatively less research has been done on alternative energy than other fields, particularly at the beginning of our sample. As a result, alternative energy starts from a lower knowledge base, leading to greater opportunities for big breakthroughs and positive spillovers than more mature technologies. Second, energy technologies may have influence in many sectors, raising the possibility that innovations will have the characteristics of General Purpose Technologies (GPT) (see, for example, Helpman, 1998).

We use two measures of social value. Both make use of patent citation data. Many researchers have used patent citations as an indicator of the value of a patent. ${ }^{19}$ First, we consider the number of patent citations received by each patent in our sample. We assume more frequently cited patents have more value to society, as they provide the building blocks to a larger number of future innovations. Second, we use a measure of patent generality described in Hall et al. (2001). Generality asks whether a patent is cited by other patents from many different technological fields, or just by other similar patents. The index ranges from $0-1$, with higher

\footnotetext{
${ }^{19}$ See, for example, Lanjouw \& Schankerman (2004) Popp (2006b), and the papers cited in Jaffe \& Trajtenberg (2002).
} 
values representing more general patents. More formally, generality is a Herfindahl index defined as

$$
\text { Generality }_{i}=1-\sum_{j}^{n_{i}} s_{i j}^{2}
$$

where $s_{i j}$ denotes the percentage of citations received by patent $i$ from patents in patent class $j$, out of a total of $n_{i}$ patent classes. Our assumption is that more general patents provide more social value, as they provide building blocks to innovations in more sectors of the economy.

Our analysis makes use of the patents from the previous section. Citation data come from the NBER patent database, which includes all citations made by patents granted between 1975 and 2002. Based on this, we restrict our analysis to patents with application years between 19751999. Table 14 provides descriptive data on generality and citations received by both energy and non-energy patents in our database. In addition, a more detailed breakdown is provided for the seven technology groups introduced for refineries in the previous section. The descriptive data suggests that alternative energy patents are cited more frequently, and are more general, than other patents.

However, simply looking at descriptive data does not tell the whole story, as citation patterns vary over time, as well as across technologies. For example, the number of opportunities to be cited is important. Patents are likely to receive more citations if there are more patents in the years immediately following publication. Moreover, older patents, such as the bulk of alternative energy patents, have had more chances to be cited than more recent patents. In addition, more recently granted patents are more likely to cite previous patents, as a result of both computerized data bases making searching for relevant patents easier, as well as increasing legal pressure to include all relevant citations in the final patent. Regression analysis 
allows us to control for such features, using fixed effects for patent application year to control for the number of citing opportunities that follow.

For both citations and generality, our regression takes the following form. Define $y_{i}$ as the variable of interest - either the subsequent citations received by patent $i$, or the generality index of patent $i$. Dummy variables indicate whether or not the patent is assigned to a firm from our alternative energy sample or our automotive sample, and whether or not the patent is an alternative energy or automotive energy patent. For non-energy patents, we also include a dummy variable for the general technology type, based on the classification system used in the NBER patent database. This accounts for the general finding that some fields are more active than others, and thus more likely to receive citations. Our regression becomes:

$$
\begin{gathered}
y_{i}=f(\text { Alternative Energy Dummy, Automotive Energy Dummy, Alternative Energy Firm } \\
\text { Dummy, Technology Dummy, year fixed effects })
\end{gathered}
$$

As many patents are never cited, we use a generalized negative binomial regression for the citation analysis, allowing the overdispersion parameter to differ for automotive and alternative energy firms. Results are reported as $e^{\beta}$, so that they can be interpreted as the likelihood of citation relative to a base case patent, a non-energy patent belonging to an automotive firm. Because generality is bounded by 0 and 1, we use a Tobit regression to examine whether energy patents are more general than other patents assigned to the firms in our sample. We do a similar analysis of refinery patents, using only dummies for the seven technology groups and year fixed effects. Because refinery patents are most likely to be crowded out, they are the excluded category.

Table 15 presents our results. Panel A confirms that both alternative energy patents and automotive energy patents are more likely to be cited than other patents from these firms. 
Interestingly, the social value of all patents from the energy companies is higher, as patents from these firms are 88 percent more likely to be cited than those from automotive firms. Alternative energy patents from these firms an additional 15 percent more likely to be cited. Automotive energy patents are 53 percent more likely to be cited than non-energy patents from these firms. Similarly, as shown in the last column, both alternative energy patents and automotive energy patents are more general than other patents from these firms.

Panel B shows the results using only patents from the 12 energy refineries, allowing us to compare the value of alternative energy patents to those most likely to be crowded out. Our excluded category is refining patents. While alternative energy patents are more general than refining patents, suggesting that they do impact more areas of the economy than the innovations they replace, their social value is not much higher. These patents are 7 percent more likely to be cited, but the result is not statistically significant. Thus, while the crowding out effect within the refining sector appears to have a positive environmental effect, by crowding out research designed to enhance the production of fossil fuels, the value of these innovations to future researchers is no different than the value of the research that is crowded out.

\section{Discussion}

As calls for increased energy R\&D strengthen, it is important to know where funding for these efforts will come from. In particular, to the extent that new energy R\&D funding crowds out other R\&D efforts, the social benefits to new energy R\&D will be dampened. Using both industry and firm-level data from the United States, this paper takes a first look at the source of energy R\&D. Using industry data, we find little evidence of crowding out across sectors. Economy wide increases in energy R\&D do not appear to draw R\&D resources away from those 
industries that are not actively involved in energy research, mitigating the concern that new energy R\&D programs will draw resources away from other innovative sectors of the economy.

Looking within sectors that do perform significant energy $\mathrm{R} \& \mathrm{D}$, the results are mixed. Industry-level regressions suggest that within-sector crowding out may be an issue, as increases in energy $R \& D$ within these industries do not appear to be associated with equivalent increases in overall R\&D within these industries. While better data are needed to substantiate this claim, the results raise the possibility that firms in these industries move $R \& D$ resources from other areas to support increases in energy R\&D. Data limitations make the results difficult to interpret, however, particularly for firms performing moderate levels of energy R\&D. One particular concern is that our energy $R \& D$ variable measures economy-wide energy $R \& D$ levels, rather than industry-specific levels.

Because of these concerns, we use firm-level patent data to take a closer look at two types of energy research. Since we combine these patent data with financial data from Compustat, our sample is restricted to large, publicly traded firms. Within these firms, we find evidence of crowding out among companies working on alternative energy technologies increases in the number of energy patents assigned to a firm do lead to decreases in other types of patents by these firms - but not for companies working on automotive technologies. Using more detailed patent data on refinery companies, we find that alternative energy research most likely crowded out innovations on refining and wells. This is consistent with the notion that any apparent crowding out reacts to market incentives - as opportunities for alternative energy research become more profitable, we would expect research opportunities for traditional fossil fuels to appear less appealing to firms. Given that the broader sample of energy firms does appear to face some financing constraints (as shown by the positive effect of sales on patents), 
we cannot conclude that the observed crowding out is only a result of firms moving resources from less profitable to more profitable ventures. However, it does suggest that any crowding out which occurred in this industry had a positive environmental effect, by enhancing greener technologies at the expense of dirtier ones.

Finally, we use patent citation data to compare the social value of energy research to other research by these firms. We find that energy patents are cited more frequently, suggesting that they provide greater value to future inventors. They are also more general as they are cited by a larger range of other patents than non-energy innovations. This is consistent with the notion that energy innovations can have a broad impact on the economy, because of the importance of energy use throughout the economy. However, confining our analysis to refineries, we find no difference in the social value of alternative energy patents compared to the refining and wells patents most likely to be crowded out by alternative energy research.

Our results have implications both for policy and for integrated assessment modelers. For policy, a key result is that any crowding out that may occur appears to affect dirty technologies. Thus, policies enhancing research incentives for green technologies have the additional desired effect of reducing incentives for research on dirty technologies such as fossil fuels. To illustrate the importance of this, consider the results of Gerlagh (2008), who presents a climate model allowing for a choice of carbon-energy producing $\mathrm{R} \& \mathrm{D}$, carbon-energy saving R\&D, and neutral R\&D. Gerlagh simulates the effect of a carbon tax on his model, and finds that carbon-producing $\mathrm{R} \& \mathrm{D}$, rather than neutral $\mathrm{R} \& \mathrm{D}$, is crowded out by induced carbon-energy saving R\&D. As a result, the impact of induced technological change is larger than in other models with crowding out, with optimal carbon taxes falling by a factor of 2 . 
For integrated assessment modelers, the results highlight the importance of incorporating the costs of R\&D in the model. Many integrated assessment models include detailed descriptions of alternative energy research, but treat other forms of technological change as exogenous. As this exogenous technological change includes research that may decline when alternative energy research increases, not adjusting this exogenous rate will double-count gains from induced technological change, even if the decrease in research results from profitmaximizing decisions of how to allocate research inputs, rather than crowding out from financial constraints. 


\section{References}

Baum, C.F., M.E. Schaffer, and S. Stillman (2007), "Enhanced routines for instrumental variables/GMM estimation and testing,” Boston College Economics Working Paper No. 667.

Bougheas, S., Görg, H., \& Strobl, E. (2003). Is R\&D Financially Constrained? Theory and Evidence from Irish Manufacturing. Review of Industrial Organization , 22, 159-174.

Buck, D., K. Hartley, and N. Hooper (1993). Defence Research and Development, CrowdingOut and the Peace Dividend. Defence Economics, 4, 161-178

Buonanno, P., Carraro, C., \& Galeotti, M. (2003). Endogenous induced technical change and the costs of Kyoto. Resource and Energy Economics , 25 (1), 11-34.

de Coninck, H., C. Fischer, R.G. Newell, and T. Ueno. 2008. International technology-oriented agreements to address climate change. Energy Policy 36:335-356.

Gerlagh R. (2008), “A Climate-Change Policy Induced Shift from Innovations in Carbon-Energy Production to Carbon-Energy Savings", Energy Economics, 30: 425-448.

Griliches, Z. (1990). Patent Statistics As Economic Indicators: A Survey. Journal of Economic Literature , 28 (4), 1661-1707.

Hall, B. H. (2002). The Financing of Research and Development. Oxford Review of Economic Policy , 18 (1), 35-51.

Hall, B.H. (1996). The private and social returns to research and development. In Smith and Barfield, Technology, R\&D and the Economy, Washington, The Brookings Institution and American Enterprise Institute, 140-162.

Hall, B. H., Jaffe, A. B., \& Trajtenberg, M. (2001). The NBER Patent Citation Database: Data File: Lessons, Insights and Methodological Tools. NBER Working Paper \#8498 .

Hall, B. H., Mairesse, J., Branstetter, L., \& Crepon, B. (1999). Does Cash Flow cause Investment and R\&D: An Exploration Using Panel Data for French, Japanese, and United States Scientific Firms. In D. Audretsch, \& R. Thurik (Eds.), Innovation, Industry Evolution, and Employment. Cambridge, England: Cambridge University Press.

Harhoff, D. (1998). Are There Financing Constraints for R\&D and Investment in German Manufacturing Firms? Annales D'Économie et de Statistique , 49/50, 421-456.

Helpman, E. (ed.) (1998) General Purpose Technologies and Economic Growth. Cambridge, MA: MIT Press.

Jaffe, A.B. (1986). Technological Opportunity and Spillovers of R\&D: Evidence from Firms' Patents, Profits, and Market Value. American Economic Review, 76(5), 984-1001.

Jaffe, A. B., \& Trajtenberg, M. (2002). Patents, Citations, \& Innovations: A Window on the Knowledge Economy. Cambridge, MA: MIT Press.

Jones, C and Williams, J. (1998). Measuring the Social Rate of Return to R\&D. Quarterly Journal of Economics, 113(4), 119-35. 
Kammen, D. M., \& Nemet, G. F. (2005). Reversing the Incredible Shrinking Energy R\&D Budget. Issues in Science and Technology , 22 (1), 84-88.

Kleibergen, F. and R. Paap (2006), "Generlized reduced rank tests using the singluar value decomposition,” Journal of Econometrics, 127(1), 97-126.

Lach, S., \& Schankerman, M. (1988). Dynamics of R\&D and Investment in the Scientific Sector. Journal of Political Economy , 97 (4), 880-904.

Lanjouw, J. O., \& Schankerman, M. (2004). Patent Quality and Research Productivity: Measuring Innovation with Multiple Indicators. Economic Journal , 114 (495), 441-465.

Lichtenberg, F. R. (1987). Changing market opportunities and the structure of R\&D investment: The case of energy. Energy Economics , 9 (3), 154-158.

Link, A.N. (1982). Productivity growth, environmental regulations and the composition of R\&D. Bell Journal of Economics, 13(2), 548-554.

Mansfield, E. (1977). Social and Private Rates of Return from Industrial Innovations. Quarterly Journal of Economics, 91, 221-240.

Mansfield, E. (1996). Estimating social and private returns from innovationsbased on the Advanced Technology Program: Problems and opportunities. NIST GCR 99-780. Gaithersburg, MD: National Institute of Standards and Technology.

Morales-Ramos, E. (2002). Defence R\&D Expenditure: The Crowding Out Hypothesis. Defence and Peace Economics, 13(5), 365-383

Mueller, M. and H.S. Atesoglu (1993). Defence Spending, Technological Change, and Economic Growth in the United States. Defence Economics, 4, 259-269

Nemet, G.F. and D.M. Kammen (2007). U.S. energy research and development: Declining investment, increasing need, and the feasibility of expansion. Energy Policy, 35, 746-755.

Newell, R.G (2007). Climate technology research, development, and demonstration: Funding sources, institutions, and instruments. Issue Brief 9 in Assessing U.S. Climate Policy Options. Washington, DC: Resources for the Future.

Nordhaus, W. D. (2002). Modeling induced innovation in climate-change policy. In A. Grübler, N. Nakicenovic, \& W. D. Nordhaus (Eds.), Technological Change and the Environment (pp. 182-209). Washington, DC: Resources for the Future.

Pakes, A. (1985). On patents, R\&D, and the stock market rate of return. Journal of Political Economy, 93(2), 390-409.

Popp, D. (2004). ENTICE: Endogenous Technological Change in the DICE Model of Global Warming. Journal of Environmental Economics and Management , 48 (1), 742-768.

Popp, D. (2005). Lessons From Patents: Using Patents to Measure Technological Change in Environmental Models. Ecological Economics , 54 (2-3), 209-226.

Popp, D. (2006a). R\&D Subsidies and Climate Policy: Is there a "Free Lunch"? Climatic Change, 77 (3-4), 311-341. 
Popp, D. (2006b). They Don't Invent Them Like They Used To: An Examination of Energy Patent Citations Over Time. Economics of Innovation and New Technology , 15 (8), 753776.

Roediger-Schluga, T. (2003). Some Micro-Evidence on the "Porter Hypothesis" from Austrian VOC Emission Standards. Growth and Change, 34(3), 359-379.

Schneider, S. H., \& Goulder, L. H. (1997). Achieving low-cost emission targets. Nature , 389, 13-14.

Staiger, D. and J.H. Stock (1997). Instrumental variables regression with weak instruments. Econometrica, 65(3), 557-586.

Yang, C.-J., \& Oppenheimer, M. (2007). A “Manhattan Project” for climate change? Climatic Change , 80 (3-4), 199-204. 
Table 1 - Descriptive Statistics by Industry, 1983-1997

\begin{tabular}{|c|c|c|c|c|c|c|}
\hline Industry & $\begin{array}{l}\text { mean } \\
\text { R\&D }\end{array}$ & $\begin{array}{c}\text { std dev } \\
\text { R\&D }\end{array}$ & mean VA & $\begin{array}{c}\text { std dev } \\
\text { VA }\end{array}$ & $\begin{array}{c}\text { mean } \\
\text { R\&D/VA }\end{array}$ & $\begin{array}{c}\text { mean } \\
\% \\
\text { energy } \\
\text { R\&D }\end{array}$ \\
\hline Petroleum refining and extraction & $2,429.25$ & 376.04 & $135,536.20$ & $33,348.48$ & $1.9 \%$ & $51.4 \%$ \\
\hline Electrical equipment & $13,196.52$ & $4,150.16$ & $125,681.77$ & $26,125.15$ & $10.4 \%$ & $8.7 \%$ \\
\hline Nonmanufacturing & $15,788.65$ & $11,779.22$ & $487,836.17$ & $84,824.31$ & $2.9 \%$ & $8.4 \%$ \\
\hline Primary metals & 817.09 & 128.02 & $49,976.08$ & $6,619.26$ & $1.7 \%$ & $7.1 \%$ \\
\hline Transportation equipment & $16,727.32$ & $3,301.58$ & $132,206.80$ & $21,309.51$ & $12.6 \%$ & $5.9 \%$ \\
\hline Fabricated metal products & 974.87 & 246.80 & $80,014.54$ & $11,812.58$ & $1.2 \%$ & $3.5 \%$ \\
\hline Chemicals and allied products & $13,944.62$ & $4,127.69$ & $117,557.85$ & $30,869.13$ & $11.8 \%$ & $3.2 \%$ \\
\hline Lumber, wood products, and furniture & 250.10 & 113.62 & $53,943.03$ & $9,914.92$ & $0.5 \%$ & $2.4 \%$ \\
\hline Rubber products & $1,077.57$ & 260.80 & $39,516.49$ & $8,706.95$ & $2.7 \%$ & $2.1 \%$ \\
\hline Machinery & $12,970.96$ & $3,099.84$ & $128,507.71$ & $15,149.11$ & $10.1 \%$ & $2.0 \%$ \\
\hline Stone, clay, and glass products & 734.05 & 253.28 & $30,349.00$ & $4,903.97$ & $2.5 \%$ & $1.9 \%$ \\
\hline Other manufacturing industries & 855.52 & 684.55 & $103,745.37$ & $18,819.92$ & $0.8 \%$ & $0.7 \%$ \\
\hline Professional and scientific instruments & $6,974.03$ & $1,639.46$ & $44,042.07$ & $11,333.53$ & $16.1 \%$ & $0.6 \%$ \\
\hline Paper and allied products & $1,082.87$ & 329.40 & $48,453.50$ & $8,702.04$ & $2.2 \%$ & $0.4 \%$ \\
\hline Food, kindred, and tobacco products & $1,460.15$ & 239.14 & $118,867.46$ & $17,700.17$ & $1.2 \%$ & $0.3 \%$ \\
\hline Textiles and apparel & 300.20 & 86.53 & $53,845.03$ & $4,486.15$ & $0.6 \%$ & $0.2 \%$ \\
\hline all industries w/energy $R \& D>5 \%$ of $R \& D$ & $9,791.77$ & $8,856.97$ & $186,247.41$ & $160,707.60$ & $5.9 \%$ & \\
\hline all industries w/energy $R \& D<5 \%$ of $R \& D$ & $3,693.18$ & $5,206.13$ & $74,440.19$ & $37,667.08$ & $4.5 \%$ & \\
\hline
\end{tabular}

NOTE: all dollar values are in 2000 dollars. Industries sorted by \% of R\&D devoted to energy R\&D. 
Table 2 - Descriptive Statistics by Industry, 1973-1997

\begin{tabular}{|c|c|c|c|c|c|c|}
\hline Industry & $\begin{array}{l}\text { mean } \\
R \& D\end{array}$ & $\begin{array}{c}\text { std dev } \\
\text { R\&D }\end{array}$ & mean VA & $\begin{array}{c}\text { std dev } \\
\text { VA }\end{array}$ & $\begin{array}{c}\text { mean } \\
\text { R\&D/VA }\end{array}$ & $\begin{array}{c}\text { mean } \\
\% \\
\text { energy } \\
\text { R\&D }\end{array}$ \\
\hline Petroleum refining and extraction & $2,163.25$ & 494.11 & $121,537.37$ & $37,845.35$ & $1.9 \%$ & $56.3 \%$ \\
\hline Nonmanufacturing & $10,706.81$ & $11,813.35$ & $443,782.35$ & $92,503.91$ & $2.0 \%$ & $16.1 \%$ \\
\hline Electrical equipment & $11,096.76$ & $4,448.64$ & $108,781.24$ & $31,859.27$ & $10.0 \%$ & $12.5 \%$ \\
\hline Primary metals & 856.10 & 121.64 & $57,170.03$ & $11,784.00$ & $1.5 \%$ & $7.7 \%$ \\
\hline Chemicals and allied products & $11,166.28$ & $5,108.05$ & $102,408.95$ & $32,669.41$ & $10.5 \%$ & $3.8 \%$ \\
\hline Fabricated metal products & 889.23 & 233.30 & $76,250.66$ & $11,096.48$ & $1.2 \%$ & $3.5 \%$ \\
\hline Machinery & $10,806.75$ & $3,938.94$ & $121,354.62$ & $16,594.16$ & $8.8 \%$ & $1.7 \%$ \\
\hline all industries w/energy $R \& D>5 \%$ of $R \& D$ & $6,205.73$ & $7,825.66$ & $182,817.75$ & $161,902.20$ & $3.9 \%$ & \\
\hline all industries w/energy $R \& D<5 \%$ of $R \& D$ & $7,620.75$ & $6,041.47$ & $100,004.74$ & $28,675.73$ & $6.8 \%$ & \\
\hline
\end{tabular}

NOTE: all dollar values are in 2000 dollars. Industries sorted by \% of R\&D devoted to energy R\&D. 
Table 3 - Industry-level Crowding Out Results, 1983-1997

A. Base results

\begin{tabular}{|c|c|c|c|c|c|c|}
\hline \multirow[b]{3}{*}{ Variable } & \multicolumn{2}{|c|}{ low energy R\&D } & \multicolumn{4}{|c|}{ high energy R\&D } \\
\hline & \multirow[b]{2}{*}{$<1 \%$} & \multirow[b]{2}{*}{$<5 \%$} & \multirow[b]{2}{*}{$>1 \%$} & \multirow[b]{2}{*}{$>5 \%$} & \multicolumn{2}{|c|}{ no refineries } \\
\hline & & & & & $>1 \%$ & $>5 \%$ \\
\hline \multirow[t]{2}{*}{$R \& D(i, t-1)$} & 0.7498 & 0.9724 & 0.8966 & 0.9332 & 0.9605 & 0.9562 \\
\hline & $(0.2201)$ & $(0.0827)$ & $(0.1016)$ & $(0.1137)$ & $(0.0898)$ & $(0.1198)$ \\
\hline \multirow[t]{2}{*}{ energy $R \& D(i, t)$} & -0.0576 & 0.0014 & 0.0744 & -0.0251 & 0.2010 & 0.1986 \\
\hline & $(0.1213)$ & $(0.0585)$ & $(0.1052)$ & $(0.1932)$ & $(0.1212)$ & $(0.1992)$ \\
\hline \multirow[t]{2}{*}{ Value Added(i,t-1) } & 0.0054 & -0.0005 & 0.0168 & 0.0125 & 0.0132 & 0.0139 \\
\hline & $(0.0036)$ & $(0.0074)$ & $(0.0108)$ & $(0.0112)$ & $(0.0117)$ & $(0.0149)$ \\
\hline \multirow[t]{2}{*}{ Federal R\&D(t-1) } & -0.0058 & -0.0061 & -0.0264 & -0.0432 & -0.0324 & -0.0618 \\
\hline & $(0.0049)$ & $(0.0051)$ & $(0.0128)$ & $(0.0235)$ & $(0.0137)$ & $(0.0345)$ \\
\hline $\mathrm{N}$ & 75 & 165 & 165 & 75 & 150 & 60 \\
\hline r2 & 0.885 & 0.712 & 0.919 & 0.948 & 0.916 & 0.949 \\
\hline p-value for Hansen's J & 0.689 & 0.156 & 0.522 & 0.970 & 0.509 & 0.983 \\
\hline Kleibergen-Paap rk Wald F stat & 0.395 & 1.540 & 1.833 & 2.093 & 3.219 & 3.035 \\
\hline underidentification test $p$-value & 0.799 & 0.149 & 0.127 & 0.256 & 0.012 & 0.082 \\
\hline
\end{tabular}

Dependent variable is all company-financed R\&D performed in industry $i$ at time $t$. Lagged R\&D and energy R\&D treated as endogenous. Instruments are Value Added $(i, t-2)$, Federal $R \& D(t-2)$, energy $R \& D(t-2)$, energy prices $(t)$, gross domestic product $(t)$, defense spending $(t)$, and federal energy R\&D spending(t-1). Standard errors in parentheses.

B. Including 3-year lagged $R \& D$ as an instrument

\begin{tabular}{|c|c|c|c|c|c|c|}
\hline \multirow[b]{3}{*}{ Variable } & \multicolumn{2}{|c|}{ low energy $R \& D$} & \multicolumn{4}{|c|}{ high energy R\&D } \\
\hline & \multirow[b]{2}{*}{$<1 \%$} & \multirow[b]{2}{*}{$<5 \%$} & \multirow[b]{2}{*}{$>1 \%$} & \multirow[b]{2}{*}{$>5 \%$} & \multicolumn{2}{|c|}{ no refineries } \\
\hline & & & & & $>1 \%$ & $>5 \%$ \\
\hline \multirow[t]{2}{*}{$R \& D(i, t-1)$} & 0.9216 & 0.8561 & 0.7207 & 0.7038 & 0.7871 & 0.7182 \\
\hline & $(0.0731)$ & $(0.1227)$ & $(0.1065)$ & $(0.1189)$ & $(0.1179)$ & $(0.1309)$ \\
\hline \multirow[t]{2}{*}{ energy $R \& D(i, t)$} & 0.0515 & 0.0361 & 0.0103 & -0.3046 & 0.3065 & 0.2279 \\
\hline & $(0.0316)$ & $(0.1113)$ & $(0.1664)$ & $(0.2641)$ & $(0.1631)$ & $(0.1837)$ \\
\hline \multirow[t]{2}{*}{ Value Added(i,t-1) } & 0.0047 & 0.0092 & 0.0336 & 0.0361 & 0.0332 & 0.0438 \\
\hline & $(0.0033)$ & $(0.0118)$ & $(0.0131)$ & $(0.0139)$ & $(0.0167)$ & $(0.0172)$ \\
\hline \multirow[t]{2}{*}{ Federal R\&D(t-1) } & -0.0086 & -0.0159 & -0.0332 & -0.0619 & -0.0532 & -0.1189 \\
\hline & $(0.0037)$ & $(0.0110)$ & $(0.0199)$ & $(0.0349)$ & $(0.0188)$ & $(0.0325)$ \\
\hline $\mathrm{N}$ & 70 & 154 & 154 & 70 & 140 & 56 \\
\hline r2 & 0.872 & 0.685 & 0.905 & 0.940 & 0.913 & 0.949 \\
\hline p-value for Hansen's J & 0.293 & 0.487 & 0.517 & 0.827 & 0.052 & 0.188 \\
\hline Kleibergen-Paap rk Wald F stat & 13.420 & 12.486 & 10.708 & 7.194 & 7.184 & 5.015 \\
\hline underidentification test p-value & 0.062 & 0.001 & 0.002 & 0.017 & 0.005 & 0.082 \\
\hline
\end{tabular}

Dependent variable is all company-financed R\&D performed in industry $i$ at time $t$. Lagged R\&D and energy R\&D treated as endogenous. Instruments are $R \& D(i, t-3)$, Value Added $(i, t-2)$, Federal $R \& D(t-2)$, energy $R \& D(t-2)$, energy prices $(t)$, gross domestic product $(t)$, defense spending $(t)$, and federal energy R\&D spending $(t-1)$. Standard errors in parentheses. 
Table 4 - Industry-level Crowding Out Results, 1973-1997

A. Base results

\begin{tabular}{|c|c|c|c|c|c|c|}
\hline \multirow[b]{3}{*}{ Variable } & \multicolumn{2}{|c|}{ low energy $R \& D$} & \multicolumn{4}{|c|}{ high energy R\&D } \\
\hline & \multirow[b]{2}{*}{$<5 \%$} & \multirow[b]{2}{*}{$<10 \%$} & \multirow[b]{2}{*}{$>5 \%$} & \multirow[b]{2}{*}{$>10 \%$} & \multicolumn{2}{|c|}{ no refineries } \\
\hline & & & & & $>5 \%$ & $>10 \%$ \\
\hline \multirow{2}{*}{$R \& D(i, t-1)$} & 0.9081 & 0.9291 & 0.8364 & 0.7939 & 1.0558 & 1.0314 \\
\hline & $(0.0896)$ & $(0.0676)$ & $(0.1067)$ & $(0.1267)$ & $(0.0690)$ & (0.0899) \\
\hline \multirow[t]{2}{*}{ energy $R \& D(i, t)$} & 0.1630 & 0.1053 & -0.4168 & -0.6402 & -0.0244 & 0.0830 \\
\hline & $(0.1783)$ & $(0.1074)$ & $(0.2027)$ & $(0.3126)$ & $(0.1368)$ & $(0.2725)$ \\
\hline \multirow[t]{2}{*}{ Value Added(i,t-1) } & 0.0170 & 0.0103 & 0.0221 & 0.0261 & 0.0042 & 0.0083 \\
\hline & $(0.0139)$ & $(0.0093)$ & $(0.0096)$ & $(0.0116)$ & $(0.0071)$ & $(0.0100)$ \\
\hline \multirow[t]{2}{*}{ Federal R\&D(t-1) } & 0.0198 & 0.0188 & -0.0129 & -0.0356 & 0.0119 & -0.0039 \\
\hline & $(0.0165)$ & $(0.0127)$ & $(0.0150)$ & $(0.0240)$ & $(0.0148)$ & $(0.0290)$ \\
\hline $\mathrm{N}$ & 69 & 92 & 92 & 69 & 69 & 46 \\
\hline r2 & 0.894 & 0.891 & 0.969 & 0.969 & 0.969 & 0.970 \\
\hline$p$-value for Hansen's J & 0.082 & 0.047 & 0.638 & 0.752 & 0.104 & 0.103 \\
\hline \multirow{2}{*}{$\begin{array}{l}\text { Kleibergen-Paap rk Wald F stat } \\
\text { underidentification test } p \text {-value }\end{array}$} & 4.922 & 4.450 & 1.001 & 0.869 & 3.876 & 4.140 \\
\hline & 0.004 & 0.003 & 0.578 & 0.675 & 0.021 & 0.031 \\
\hline
\end{tabular}

Dependent variable is all company-financed R\&D performed in industry $i$ at time $t$. Lagged R\&D and energy R\&D treated as endogenous. Instruments are Value Added $(i, t-2)$, Federal $R \& D(t-2)$, energy $R \& D(t-2)$, energy prices $(t)$, gross domestic product $(t)$, defense spending $(t)$, and federal energy R\&D spending(t-1). Standard errors in parentheses.

B. Including 3-year lagged $R \& D$ as an instrument

\begin{tabular}{|c|c|c|c|c|c|c|}
\hline \multirow[b]{3}{*}{ Variable } & \multicolumn{2}{|c|}{ low energy $R \& D$} & \multicolumn{4}{|c|}{ high energy R\&D } \\
\hline & \multirow[b]{2}{*}{$<1 \%$} & \multirow[b]{2}{*}{$<5 \%$} & \multirow[b]{2}{*}{$>1 \%$} & \multirow[b]{2}{*}{$>5 \%$} & \multicolumn{2}{|c|}{ no refineries } \\
\hline & & & & & $>1 \%$ & $>5 \%$ \\
\hline \multirow[t]{2}{*}{$R \& D(i, t-1)$} & 0.8897 & 0.9154 & 0.7936 & 0.7369 & 0.9384 & 0.8366 \\
\hline & $(0.1045)$ & $(0.0870)$ & $(0.0945)$ & $(0.1102)$ & $(0.1015)$ & $(0.1188)$ \\
\hline \multirow[t]{2}{*}{ energy $R \& D(i, t)$} & 0.1438 & 0.0562 & -0.5043 & -0.7504 & -0.3448 & -0.7371 \\
\hline & $(0.2170)$ & $(0.1320)$ & $(0.1637)$ & $(0.2390)$ & $(0.1661)$ & $(0.2669)$ \\
\hline \multirow[t]{2}{*}{ Value Added(i,t-1) } & 0.0204 & 0.0128 & 0.0255 & 0.0314 & 0.0132 & 0.0250 \\
\hline & $(0.0165)$ & $(0.0118)$ & $(0.0096)$ & $(0.0118)$ & $(0.0113)$ & $(0.0138)$ \\
\hline \multirow[t]{2}{*}{ Federal R\&D(t-1) } & 0.0203 & 0.0186 & -0.0165 & -0.0429 & -0.0087 & -0.0492 \\
\hline & $(0.0190)$ & $(0.0159)$ & $(0.0178)$ & $(0.0291)$ & $(0.0216)$ & $(0.0337)$ \\
\hline $\mathrm{N}$ & 69 & 92 & 92 & 69 & 69 & 46 \\
\hline r2 & 0.895 & 0.893 & 0.967 & 0.967 & 0.971 & 0.973 \\
\hline p-value for Hansen's J & 0.234 & 0.181 & 0.857 & 0.933 & 0.022 & 0.006 \\
\hline Kleibergen-Paap rk Wald F stat & 10.308 & 10.721 & 12.603 & 9.056 & 10.820 & 6.607 \\
\hline underidentification test $p$-value & 0.004 & 0.002 & 0.003 & 0.007 & 0.023 & 0.048 \\
\hline
\end{tabular}

Dependent variable is all company-financed R\&D performed in industry $i$ at time $t$. Lagged R\&D and energy R\&D treated as endogenous. Instruments are $R \& D(i, t-3)$, Value Added $(i, t-2)$, Federal $R \& D(t-2)$, energy $R \& D(t-2)$, energy prices $(t)$, gross domestic $\operatorname{product}(t)$, defense spending $(t)$, and federal energy R\&D spending $(t-1)$. Standard errors in parentheses. 
Table 5 - Industry-Level Crowding Out with Estimated Energy R\&D

\begin{tabular}{|c|c|c|c|c|c|c|c|c|}
\hline \multirow[b]{3}{*}{ Variable } & \multicolumn{4}{|c|}{ high energy R\&D 1973-1997 } & \multicolumn{4}{|c|}{ high energy R\&D 1983-1997 } \\
\hline & \multirow[b]{2}{*}{$>5 \%$} & \multirow[b]{2}{*}{$>10 \%$} & \multicolumn{2}{|c|}{ no refineries } & \multirow[b]{2}{*}{$>1 \%$} & \multirow[b]{2}{*}{$>5 \%$} & \multicolumn{2}{|c|}{ no refineries } \\
\hline & & & $>5 \%$ & $>10 \%$ & & & $>1 \%$ & $>5 \%$ \\
\hline \multirow[t]{2}{*}{$R \& D(i, t-1)$} & 0.8335 & 0.8435 & 1.0587 & 1.0403 & 0.9525 & 0.9295 & 1.0062 & 0.9550 \\
\hline & $(0.1113)$ & $(0.1107)$ & $(0.0678)$ & $(0.0912)$ & $(0.0832)$ & $(0.0936)$ & $(0.0870)$ & $(0.1208)$ \\
\hline \multirow[t]{2}{*}{ energy $R \& D(i, t)$} & -1.4906 & -1.3663 & 0.2666 & 1.4106 & -0.2777 & -0.3585 & 2.9388 & 3.4952 \\
\hline & $(0.8972)$ & $(0.8556)$ & $(1.3385)$ & $(2.0013)$ & $(0.4846)$ & $(0.5104)$ & $(2.8544)$ & $(2.9155)$ \\
\hline \multirow{2}{*}{ Value Added(i,t-1) } & 0.0246 & 0.0247 & 0.0040 & 0.0081 & 0.0099 & 0.0129 & 0.0080 & 0.0151 \\
\hline & $(0.0109)$ & $(0.0113)$ & $(0.0069)$ & $(0.0100)$ & $(0.0089)$ & $(0.0105)$ & $(0.0111)$ & $(0.0150)$ \\
\hline \multirow[t]{2}{*}{ Federal $R \& D(t-1)$} & -0.0182 & -0.0387 & 0.0130 & -0.0036 & -0.0258 & -0.0439 & -0.0303 & -0.0641 \\
\hline & $(0.0175)$ & $(0.0264)$ & $(0.0149)$ & $(0.0288)$ & $(0.0119)$ & $(0.0234)$ & $(0.0140)$ & $(0.0345)$ \\
\hline $\mathrm{N}$ & 92 & 69 & 69 & 46 & 165 & 75 & 150 & 60 \\
\hline r2 & 0.968 & 0.969 & 0.969 & 0.970 & 0.916 & 0.948 & 0.912 & 0.948 \\
\hline $\mathrm{p}$-value for Hansen's J & 0.762 & 0.778 & 0.101 & 0.128 & 0.339 & 0.956 & 0.434 & 0.939 \\
\hline \multirow{2}{*}{$\begin{array}{l}\text { Kleibergen-Paap rk Wald } F \text { stat } \\
\text { underidentification test } p \text {-value }\end{array}$} & 1.366 & 1.487 & 4.383 & 4.092 & 3.693 & 2.560 & 4.511 & 3.418 \\
\hline & 0.452 & 0.418 & 0.012 & 0.032 & 0.011 & 0.300 & 0.005 & 0.061 \\
\hline
\end{tabular}

$\overline{\text { The table presents results using estimated values for energy R\&D for each industry, as described in the text. Dependent variable is all company- }}$ financed $R \& D$ performed in industry $i$ at time $t$. Lagged $R \& D$ and energy $R \& D$ treated as endogenous. Instruments are Value Added(i,t-2), Federal $R \& D(t-2)$, energy $R \& D(t-2)$, energy prices $(t)$, gross domestic product $(t)$, defense spending $(t)$, and federal energy $R \& D$ spending $(t-1)$. Standard errors in parentheses. 
Table 6 Descriptive Statistics by Firm

\begin{tabular}{|c|c|c|c|c|c|c|c|c|c|c|c|}
\hline Company & Freq. & $\begin{array}{c}\text { alt. } \\
\text { energy } \\
\text { patents }\end{array}$ & $\begin{array}{c}\text { auto } \\
\text { energy } \\
\text { patents }\end{array}$ & $\begin{array}{c}\text { all } \\
\text { patents }\end{array}$ & $\begin{array}{c}\text { pct alt } \\
\text { energy } \\
\text { (average) }\end{array}$ & $\begin{array}{l}\text { pct alt } \\
\text { energy } \\
\text { (pct of } \\
\text { total) }\end{array}$ & $\begin{array}{c}\text { pct auto } \\
\text { energy } \\
\text { (average) }\end{array}$ & $\begin{array}{c}\text { pct } \\
\text { auto } \\
\text { energy } \\
\text { (pct of } \\
\text { total) }\end{array}$ & $\begin{array}{c}\text { Capital } \\
\text { (billions } \\
2000 \text { \$) }\end{array}$ & $\begin{array}{c}\text { Sales } \\
\text { (billions } \\
2000 \text { \$) }\end{array}$ & $\begin{array}{c}\text { Debt } \\
\text { (billions } \\
2000 \text { \$) }\end{array}$ \\
\hline Ametek, Inc. & 30 & 0.53 & & 6.27 & $9.39 \%$ & $8.51 \%$ & & & 0.15 & 0.70 & 0.10 \\
\hline Amoco Corporation & 28 & 2.21 & 0.50 & 90.36 & $2.47 \%$ & $2.45 \%$ & $0.58 \%$ & $0.55 \%$ & 20.67 & 27.98 & 3.27 \\
\hline Atlantic Richfield & 30 & 4.20 & 0.27 & 72.00 & $5.23 \%$ & $5.83 \%$ & $0.38 \%$ & $0.37 \%$ & 16.71 & 20.77 & 4.43 \\
\hline Babcock \& Wilcox & 7 & 0.57 & 0.00 & 32.29 & $1.44 \%$ & $1.77 \%$ & $0.00 \%$ & $0.00 \%$ & 0.76 & 3.29 & 0.11 \\
\hline Chevron & 30 & 3.60 & 0.67 & 102.00 & $2.77 \%$ & $3.53 \%$ & $0.68 \%$ & $0.65 \%$ & 20.48 & 37.47 & 3.96 \\
\hline Chrysler & 28 & & 2.04 & 65.39 & & & $3.37 \%$ & $3.11 \%$ & 8.75 & 33.39 & 4.90 \\
\hline Cities Service Company & 17 & 1.06 & & 21.12 & $10.65 \%$ & $5.01 \%$ & & & 5.02 & 6.99 & 0.98 \\
\hline Combustion Engineering & 19 & 3.05 & 0.05 & 54.63 & $5.26 \%$ & $5.59 \%$ & $0.15 \%$ & $0.10 \%$ & 0.79 & 4.04 & 0.13 \\
\hline Conoco & 30 & 1.47 & & 47.93 & $2.15 \%$ & $3.06 \%$ & & & 9.23 & 14.45 & 2.67 \\
\hline Cummins Engine Co. & 30 & & 2.67 & 20.77 & & & $8.63 \%$ & $12.84 \%$ & 0.93 & 3.47 & 0.31 \\
\hline Daimler-Benz & 10 & 0.40 & 2.20 & 98.50 & $0.38 \%$ & $0.41 \%$ & $1.79 \%$ & $2.23 \%$ & 17.69 & 67.31 & 5.06 \\
\hline Daimler-Chrysler & 2 & 3.00 & 19.50 & 560.00 & $0.69 \%$ & $0.54 \%$ & $3.71 \%$ & $3.48 \%$ & 61.56 & 162.32 & 25.69 \\
\hline Detroit Diesel & 8 & & 1.50 & 8.25 & & & $14.32 \%$ & $18.18 \%$ & 0.25 & 2.07 & 0.06 \\
\hline Dorr-Oliver & 9 & 0.89 & & 8.33 & $10.34 \%$ & $10.67 \%$ & & & 0.02 & 0.30 & 0.00 \\
\hline Energy Conversion Devices & 30 & 3.07 & 0.27 & 13.10 & $14.33 \%$ & $23.41 \%$ & $2.65 \%$ & $2.04 \%$ & 0.01 & 0.02 & 0.00 \\
\hline Engelhard Corporation & 19 & 1.32 & 2.11 & 24.16 & $5.89 \%$ & $5.45 \%$ & $9.45 \%$ & $8.71 \%$ & 0.60 & 3.13 & 0.19 \\
\hline Exxon & 30 & 11.07 & 2.20 & 240.70 & $4.38 \%$ & $4.60 \%$ & $0.88 \%$ & $0.91 \%$ & 57.55 & 110.49 & 5.40 \\
\hline Ford Motor Company & 30 & 0.83 & 8.00 & 233.73 & $0.51 \%$ & $0.36 \%$ & $2.96 \%$ & $3.42 \%$ & 20.84 & 92.64 & 24.72 \\
\hline Foster Wheeler & 30 & 3.43 & & 17.57 & $19.69 \%$ & $19.54 \%$ & & & 0.38 & 2.41 & 0.25 \\
\hline Grumman Aerospace & 24 & 0.83 & & 29.25 & $4.77 \%$ & $2.85 \%$ & & & 0.40 & 3.39 & 0.32 \\
\hline Gulf & 12 & 5.08 & 0.00 & 79.50 & $6.13 \%$ & $6.39 \%$ & $0.00 \%$ & $0.00 \%$ & 0.05 & 0.04 & 0.02 \\
\hline Honda & 30 & 0.93 & 8.17 & 215.63 & $0.23 \%$ & $0.43 \%$ & $2.99 \%$ & $3.79 \%$ & 5.13 & 23.80 & 2.27 \\
\hline Kerr-McGee & 30 & 0.97 & 0.03 & 3.30 & $26.24 \%$ & $29.29 \%$ & $2.00 \%$ & $1.01 \%$ & 2.59 & 3.50 & 0.63 \\
\hline Lubrizol & 30 & & 1.23 & 27.43 & & & $4.18 \%$ & $4.50 \%$ & 0.41 & 1.30 & 0.07 \\
\hline
\end{tabular}

(table continued on next page) 
Table 6 Descriptive Statistics by Firm (continued)

\begin{tabular}{|c|c|c|c|c|c|c|c|c|c|c|c|}
\hline Company & Freq. & $\begin{array}{c}\text { alt. } \\
\text { energy } \\
\text { patents }\end{array}$ & $\begin{array}{c}\text { auto } \\
\text { energy } \\
\text { patents }\end{array}$ & $\begin{array}{c}\text { all } \\
\text { patents }\end{array}$ & $\begin{array}{c}\text { pct alt } \\
\text { energy } \\
\text { (average) }\end{array}$ & $\begin{array}{l}\text { pct alt } \\
\text { energy } \\
\text { (pct of } \\
\text { total) }\end{array}$ & $\begin{array}{c}\text { pct auto } \\
\text { energy } \\
\text { (average) }\end{array}$ & $\begin{array}{c}\text { pct } \\
\text { auto } \\
\text { energy } \\
\text { (pct of } \\
\text { total) }\end{array}$ & $\begin{array}{c}\text { Capital } \\
\text { (billions } \\
2000 \$ \text { ) }\end{array}$ & $\begin{array}{c}\text { Sales } \\
\text { (billions } \\
2000 \text { \$) }\end{array}$ & $\begin{array}{c}\text { Debt } \\
\text { (billions } \\
2000 \text { \$) }\end{array}$ \\
\hline Mobil & 29 & 4.59 & 3.31 & 224.86 & $1.89 \%$ & $2.04 \%$ & $1.40 \%$ & $1.47 \%$ & 24.40 & 60.91 & 4.37 \\
\hline Molten Metal Technology & 5 & 1.60 & & 6.60 & $22.67 \%$ & $24.24 \%$ & & & 0.04 & 0.03 & 0.04 \\
\hline Nissan & 11 & 0.00 & 6.55 & 213.73 & $0.00 \%$ & $0.00 \%$ & $2.99 \%$ & $3.06 \%$ & 26.92 & 56.98 & 15.32 \\
\hline Occidental & 30 & 2.67 & 0.37 & 29.73 & $6.94 \%$ & $8.97 \%$ & $1.18 \%$ & $1.23 \%$ & 10.20 & 14.74 & 3.78 \\
\hline Optical Coating Laboratory & 30 & 0.37 & & 4.50 & $9.13 \%$ & $8.15 \%$ & & & 0.05 & 0.11 & 0.02 \\
\hline Owens-Illinois & 30 & 1.23 & & 65.53 & $1.34 \%$ & $1.88 \%$ & & & 2.29 & 4.89 & 1.84 \\
\hline Praxair Technology & 9 & 1.33 & 0.56 & 55.56 & $2.53 \%$ & $2.40 \%$ & $1.07 \%$ & $1.00 \%$ & 3.64 & 3.83 & 1.47 \\
\hline Sanyo Electric & 10 & 6.50 & 2.40 & 188.40 & $4.14 \%$ & $3.45 \%$ & $1.34 \%$ & $1.27 \%$ & 5.19 & 16.12 & 3.31 \\
\hline Spire Corp. & 18 & 0.44 & 2.72 & & $13.97 \%$ & $16.33 \%$ & & & 0.01 & 0.02 & 0.00 \\
\hline Standard Oil & 17 & 2.12 & 0.29 & 77.53 & $2.75 \%$ & $2.73 \%$ & $0.41 \%$ & $0.38 \%$ & 10.45 & 10.46 & 2.75 \\
\hline Texaco & 30 & 3.57 & 0.50 & 140.97 & $2.76 \%$ & $2.53 \%$ & $0.49 \%$ & $0.35 \%$ & 20.09 & 47.28 & 4.29 \\
\hline Tosco Corporation & 30 & 0.30 & & 1.03 & $25.97 \%$ & $29.03 \%$ & & & 0.86 & 3.87 & 0.49 \\
\hline Toyota & 18 & 2.44 & 13.67 & 266.11 & $0.70 \%$ & $0.92 \%$ & $4.65 \%$ & $5.14 \%$ & 20.44 & 75.09 & 10.47 \\
\hline United Technologies & 30 & 6.13 & 5.47 & 178.30 & $3.58 \%$ & $3.44 \%$ & $3.16 \%$ & $3.07 \%$ & 3.31 & 18.20 & 1.27 \\
\hline UOP & 8 & 5.38 & 0.25 & 181.88 & $2.99 \%$ & $2.96 \%$ & $0.16 \%$ & $0.14 \%$ & 0.33 & 1.67 & 0.07 \\
\hline Varian Associates & 28 & 0.79 & & 35.36 & $2.28 \%$ & $2.22 \%$ & & & 0.21 & 1.12 & 0.05 \\
\hline Volvo & 17 & 0.06 & 0.41 & 20.53 & $0.45 \%$ & $0.29 \%$ & $1.90 \%$ & $2.01 \%$ & 3.58 & 18.70 & 1.74 \\
\hline Westinghouse Electric & 22 & 6.82 & 4.82 & 423.96 & $1.70 \%$ & $1.61 \%$ & $1.21 \%$ & $1.14 \%$ & 3.28 & 13.83 & 0.63 \\
\hline
\end{tabular}

The table shows average values for variables, by firm. The columns labeled "pct energy (pct of total)" are the percentage of energy patents in the firms total patent portfolio (column3 or 4 divided by column 5). Columns labeled "pct energy (average)" show the average of the annual share of energy patents for each firm. Only patents with application years between 1970 \& 1999 are used for this table, as these cutoffs are used in the regression analysis that follows. 
Table 7 - Top Patent Assignees by Field, 1971-2002

\section{A. Alternative Energy}

\begin{tabular}{lccc}
\hline \hline Assignee & $\begin{array}{c}\text { Energy } \\
\text { patents }\end{array}$ & $\begin{array}{c}\text { All } \\
\text { patents }\end{array}$ & $\begin{array}{c}\% \\
\text { energy }\end{array}$ \\
\hline Individually Owned Patents & 4457 & 521560 & $0.85 \%$ \\
Exxon & 340 & 7839 & $4.34 \%$ \\
Canon & 318 & 24454 & $1.30 \%$ \\
US Department of Energy & 303 & 6028 & $5.03 \%$ \\
Siemens Aktiengesellschaft & 216 & 16024 & $1.35 \%$ \\
United Technologies & 201 & 5655 & $3.55 \%$ \\
Westinghouse Electric & 180 & 10891 & $1.65 \%$ \\
International Fuel Cells Corporation & 179 & 244 & $73.36 \%$ \\
General Electric & 147 & 27557 & $0.53 \%$ \\
Mobil & 137 & 6798 & $2.02 \%$ \\
Atlantic Richfield Copmany & 131 & 2323 & $5.64 \%$ \\
Sanyo Electric & 122 & 3047 & $4.00 \%$ \\
Hitachi & 116 & 24920 & $0.47 \%$ \\
Texaco & 115 & 4523 & $2.54 \%$ \\
Chevron & 111 & 3332 & $3.33 \%$ \\
Foster Wheeler & 106 & 565 & $18.76 \%$ \\
NASA & 106 & 4177 & $2.54 \%$ \\
Mitsubishi & 101 & 20951 & $0.48 \%$ \\
Energy Conversion Devices, Inc. & 94 & 429 & $21.91 \%$ \\
Fuji Electric & 91 & 1478 & $6.16 \%$ \\
TOTAL (top 20 except individuals) & 3114 & & \\
\hline ALL ASSIGNEES & 18107 & 2933721 & $0.62 \%$ \\
\hline \hline
\end{tabular}

\section{B. Automotive Energy Patents}

\begin{tabular}{lccc}
\hline \hline Assignee & $\begin{array}{c}\text { Energy } \\
\text { patents }\end{array}$ & $\begin{array}{c}\text { All } \\
\text { patents }\end{array}$ & $\begin{array}{c}\% \\
\text { energy }\end{array}$ \\
\hline Individually Owned Patents & 1624 & 521560 & $0.31 \%$ \\
Ford Motor Company & 345 & 7785 & $4.43 \%$ \\
Toyota & 335 & 7083 & $4.73 \%$ \\
Honda & 300 & 7243 & $4.14 \%$ \\
Nissan & 209 & 6947 & $3.01 \%$ \\
International Fuel Cells Corporation & 199 & 244 & $81.56 \%$ \\
United Technologies Corporation & 181 & 5655 & $3.20 \%$ \\
General Motors & 180 & 11408 & $1.58 \%$ \\
Mitsubishi & 159 & 20951 & $0.76 \%$ \\
Hitachi & 153 & 24920 & $0.61 \%$ \\
General Electric & 150 & 27557 & $0.54 \%$ \\
Westinghouse Electric & 138 & 10891 & $1.27 \%$ \\
Siemens Aktiengesellschaft & 133 & 16024 & $0.83 \%$ \\
Robert Bosch & 108 & 9002 & $1.20 \%$ \\
Mobil & 98 & 6798 & $1.44 \%$ \\
US Department of Energy & 98 & 6028 & $1.63 \%$ \\
Daimler-Chrysler & 88 & 2196 & $4.01 \%$ \\
Cummins Engine Company & 85 & 682 & $12.46 \%$ \\
Ballard Power Systems & 84 & 90 & $93.33 \%$ \\
NGK Insulators Ltd. & 82 & 2597 & $3.16 \%$ \\
TOTAL (top 20 except individuals) & 3125 & & \\
\hline ALL ASSIGNEES & 9895 & 2933721 & $0.34 \%$ \\
\hline \hline
\end{tabular}


Table 8 - Top Patent Assignees, by\% of Patents Pertaining to Energy, by Field, 1971-2002

\section{A. Alternative Energy}

\begin{tabular}{lccc}
\hline \hline Assignee & $\begin{array}{c}\text { Energy } \\
\text { patents }\end{array}$ & $\begin{array}{c}\text { All } \\
\text { patents }\end{array}$ & $\begin{array}{c}\% \\
\text { energy }\end{array}$ \\
\hline JX Crystals, Inc. & 23 & 23 & $100.00 \%$ \\
Solarco Corporation & 12 & 12 & $100.00 \%$ \\
Sunworks, Inc. & 12 & 12 & $100.00 \%$ \\
Magma Power Company & 10 & 10 & $100.00 \%$ \\
H-Power Corp. & 15 & 16 & $93.75 \%$ \\
Electrochemische Energieconversie & 12 & 13 & $92.31 \%$ \\
Solarex Corporation & 55 & 60 & $91.67 \%$ \\
M-C Power Corporation & 11 & 12 & $91.67 \%$ \\
Chronar Corporation & 24 & 27 & $88.89 \%$ \\
Plug Power L.L.C. & 53 & 60 & $88.33 \%$ \\
Sovoncis Solar Systems & 19 & 23 & $82.61 \%$ \\
Spectrolab, Inc. & 13 & 16 & $81.25 \%$ \\
ZTek Corporation & 13 & 16 & $81.25 \%$ \\
Ballard Power Sytems, Inc. & 73 & 90 & $81.11 \%$ \\
Astropower, Inc. & 12 & 15 & $80.00 \%$ \\
AER Energy Resources, Inc. & 38 & 49 & $77.55 \%$ \\
United Solar Systems Corporation & 33 & 44 & $75.00 \%$ \\
International Fuel Cells Corp. & 179 & 244 & $73.36 \%$ \\
Evergreen Solar, Inc. & 11 & 15 & $73.33 \%$ \\
Photon Power, Inc. & 16 & 23 & $69.57 \%$ \\
TOTAL (top 20) & 634 & & \\
\hline ALL ASSIGNEES & 18107 & 2933721 & $0.62 \%$ \\
\hline \hline
\end{tabular}

B. Automotive Energy Patents

\begin{tabular}{lccc}
\hline \hline Assignee & $\begin{array}{c}\text { Energy } \\
\text { patents }\end{array}$ & $\begin{array}{c}\text { All } \\
\text { patents }\end{array}$ & $\begin{array}{c}\% \\
\text { energy }\end{array}$ \\
\hline H-Power Corp. & 16 & 16 & $100.00 \%$ \\
ZTek Corporation & 16 & 16 & $100.00 \%$ \\
Ballard Power Systems, Inc. & 84 & 90 & $93.33 \%$ \\
Plug Power L.L.C. & 54 & 60 & $90.00 \%$ \\
M-C Power Corporation & 10 & 12 & $83.33 \%$ \\
International Fuel Cells Corp. & 199 & 244 & $81.56 \%$ \\
Phillips \& Temro Industries, Inc. & 11 & 16 & $68.75 \%$ \\
Energy Research Corporation & 58 & 91 & $63.74 \%$ \\
National Power PLC & 11 & 19 & $57.89 \%$ \\
Xcellsis GmbH & 17 & 31 & $54.84 \%$ \\
Electric Fuel Limited & 16 & 36 & $44.44 \%$ \\
AER Energy Resources, Inc & 18 & 49 & $36.73 \%$ \\
Kabushikikaiha Equos Research & 23 & 64 & $35.94 \%$ \\
Lynntech, Inc. & 21 & 61 & $34.43 \%$ \\
Energy Development Associates & 21 & 68 & $30.88 \%$ \\
Tanaka Kikinzoku Kogyo K.K. & 19 & 77 & $24.68 \%$ \\
Reveo, Inc. & 19 & 77 & $24.68 \%$ \\
SMH Management Services & 10 & 53 & $18.87 \%$ \\
Detroit Diesel Corporation & 19 & 113 & $16.81 \%$ \\
Ceramatec, Inc. & 10 & 61 & $16.39 \%$ \\
TOTAL (top 20) & 652 & & \\
\hline ALL ASSIGNEES & 9895 & 2933721 & $0.34 \%$ \\
\hline \hline
\end{tabular}


Table 9 - Crowding Out from Alternative Energy Patents

\begin{tabular}{lcccccc}
\hline \hline Variable & $\mathbf{( 1 )}$ & $\mathbf{( 2 )}$ & $\mathbf{( 3 )}$ & $\mathbf{( 4 )}$ & $\mathbf{( 5 )}$ & $\mathbf{( 6 )}$ \\
\hline Other Patents (t-1) & 0.809 & 0.691 & 0.612 & 0.918 & 0.866 & 0.759 \\
& $(6.194)$ & $(3.829)$ & $(3.075)$ & $(6.264)$ & $(4.379)$ & $(3.495)$ \\
Energy Patents(t) & -1.650 & -1.486 & -1.131 & -1.234 & -1.190 & -0.925 \\
& $(-2.031)$ & $(-1.800)$ & $(-1.799)$ & $(-1.512)$ & $(-1.483)$ & $(-1.372)$ \\
Sales (t-1) & 0.584 & 0.765 & 0.809 & 0.440 & 0.509 & 0.565 \\
& $(1.733)$ & $(1.970)$ & $(1.658)$ & $(1.276)$ & $(1.266)$ & $(1.151)$ \\
Capital(t) & -0.776 & -0.549 & & -0.819 & -0.607 & \\
& $(-1.617)$ & $(-1.029)$ & & $(-1.659)$ & $(-1.164)$ & \\
Debt(t) & -0.022 & & & 0.704 & & \\
& $(-0.018)$ & & & $(0.546)$ & & \\
trend & & & & -0.595 & -0.622 & -0.814 \\
& & & & $(-2.302)$ & $(-1.891)$ & $(-2.470)$ \\
Year Dummies & YES & YES & YES & NO & NO & NO \\
\hline $\mathrm{N}$ & 608 & 608 & 608 & 608 & 608 & 608 \\
r2 & 0.616 & 0.620 & 0.616 & 0.584 & 0.597 & 0.613 \\
p-value for Hansen's J & 0.654 & 0.886 & 0.647 & 0.775 & 0.991 & 0.942 \\
Kleibergen-Paap rk Wald F stat & 2.628 & 2.658 & 3.990 & 2.603 & 2.727 & 3.837 \\
underidentification test p-value & 0.004 & 0.011 & 0.001 & 0.010 & 0.025 & 0.004 \\
\hline \hline
\end{tabular}

NOTE: Dependent variable is Other Patents $(t)$. T-statistics presented under estimates. 1 \& 2 year lagged independent variables and 2-year lagged energy patents used as instruments for Other Patents( $(t-1)$ and Energy Patents. Regressions run from 1973-1999, with lagged data back to 1970 used for instruments. Energy prices and lagged energy prices also used as instruments in (4)-(6). 
Table 10 - Crowding Out from Alternative Energy Patents - Additional Specifications

\begin{tabular}{lcccccc}
\hline \hline Variable & $\mathbf{( 1 )}$ & $\mathbf{( 2 )}$ & $\mathbf{( 3 )}$ & $\mathbf{( 4 )}$ & $\mathbf{( 5 )}$ & $\mathbf{( 6 )}$ \\
\hline Other Patents (t-1) & 0.809 & 0.711 & & 0.918 & 0.724 & \\
& $(6.194)$ & $(10.639)$ & & $(6.264)$ & $(10.236)$ & \\
Energy Patents(t) & -1.650 & -1.618 & -1.439 & -1.234 & -1.130 & -1.440 \\
& $(-2.031)$ & $(-2.033)$ & $(-1.354)$ & $(-1.512)$ & $(-1.448)$ & $(-1.446)$ \\
Sales (t-1) & 0.584 & 0.753 & 1.994 & 0.440 & 0.697 & 1.811 \\
& $(1.733)$ & $(2.442)$ & $(5.164)$ & $(1.276)$ & $(2.218)$ & $(4.690)$ \\
Capital(t) & -0.776 & -0.598 & 0.677 & -0.819 & -0.426 & 0.777 \\
& $(-1.617)$ & $(-1.293)$ & $(0.891)$ & $(-1.659)$ & $(-0.892)$ & $(0.997)$ \\
Debt(t) & -0.022 & -0.225 & -1.718 & 0.704 & 0.487 & -0.390 \\
& $(-0.018)$ & $(-0.178)$ & $(-0.892)$ & $(0.546)$ & $(0.368)$ & $(-0.196)$ \\
trend & & & & -0.595 & -0.845 & -1.856 \\
& & & & $(-2.302)$ & $(-4.865)$ & $(-6.702)$ \\
Year Dummies & YES & YES & YES & NO & NO & NO \\
\hline $\mathrm{N}$ & 608 & 608 & 608 & 608 & 608 & 608 \\
r2 & 0.616 & 0.618 & 0.180 & 0.584 & 0.610 & 0.144 \\
$\mathrm{p}$-value for Hansen's J & 0.654 & 0.687 & 0.031 & 0.775 & 0.445 & 0.032 \\
Kleibergen-Paap rk Wald F stat & 2.628 & 11.112 & 13.034 & 2.603 & 11.604 & 13.643 \\
underidentification test p-value & 0.004 & $2.1 \mathrm{E}-09$ & $3.7 \mathrm{E}-09$ & 0.010 & $5.4 \mathrm{E}-11$ & $5.9 \mathrm{E}-11$ \\
\hline \hline
\end{tabular}

NOTE: Dependent variable is Other Patents $(t)$. T-statistics presented under estimates. 1 \& 2 year lagged independent variables and 2-year lagged energy patents used as instruments for Other Patents $(t-1)$ and Energy Patents. Regressions run from 1973-1999, with lagged data back to 1970 used for instruments. Energy prices and lagged energy prices also used as instruments in (4)-(6). Other Patents(t-3) also used as an instrument in columns (2) and (5). 
Table 11 - Crowding Out from Automotive Energy Patents

\begin{tabular}{lcccccc}
\hline \hline Variable & $\mathbf{( 1 )}$ & $\mathbf{( 2 )}$ & $\mathbf{( 3 )}$ & $\mathbf{( 4 )}$ & $\mathbf{( 5 )}$ & $\mathbf{( 6 )}$ \\
\hline Other Patents (t-1) & 0.417 & 0.504 & 0.272 & 0.477 & 0.552 & 0.365 \\
& $(1.272)$ & $(1.390)$ & $(0.797)$ & $(1.369)$ & $(1.444)$ & $(1.045)$ \\
Energy Patents(t) & -0.511 & -1.602 & 1.036 & -0.729 & -1.633 & 0.922 \\
& $(-0.171)$ & $(-0.434)$ & $(0.336)$ & $(-0.267)$ & $(-0.470)$ & $(0.337)$ \\
Sales (t-1) & 1.014 & 0.404 & 2.108 & 0.587 & 0.063 & 1.709 \\
& $(0.817)$ & $(0.380)$ & $(1.958)$ & $(0.461)$ & $(0.058)$ & $(1.880)$ \\
Capital(t) & 4.655 & 5.210 & & 5.016 & 5.514 & \\
& $(1.706)$ & $(1.793)$ & & $(1.767)$ & $(1.803)$ & \\
Debt(t) & -0.788 & & & -0.715 & & \\
& $(-0.973)$ & & & $(-0.870)$ & & \\
trend & & & & 0.578 & 0.504 & 0.782 \\
& & & & $(0.740)$ & $(0.608)$ & $(0.908)$ \\
Year Dummies & YES & YES & YES & NO & NO & NO \\
\hline $\mathrm{N}$ & 254 & 254 & 254 & 254 & 254 & 254 \\
r2 & 0.703 & 0.692 & 0.660 & 0.690 & 0.681 & 0.653 \\
$\mathrm{p}$-value for Hansen's J & 0.194 & 0.053 & 0.081 & 0.168 & 0.040 & 0.109 \\
Kleibergen-Paap rk Wald F stat & 1.667 & 2.287 & 2.686 & 1.673 & 2.283 & 2.939 \\
underidentification test p-value & 0.255 & 0.121 & 0.035 & 0.280 & 0.148 & 0.031 \\
\hline \hline
\end{tabular}

NOTE: Dependent variable is Other Patents $(t)$. T-statistics presented under estimates. 1 \& 2 year lagged independent variables and 2-year lagged energy patents used as instruments for Other Patents( $t-1)$ and Energy Patents. Regressions run from 1973-1999, with lagged data back to 1970 used for instruments. Energy prices and lagged energy prices also used as instruments in (4)-(6). 
Table 12 - Crowding Out from Automotive Energy Patents - Alternative Specifications

\begin{tabular}{lcccccc}
\hline \hline Variable & $\mathbf{( 1 )}$ & $\mathbf{( 2 )}$ & $\mathbf{( 3 )}$ & $\mathbf{( 4 )}$ & $\mathbf{( 5 )}$ & $\mathbf{( 6 )}$ \\
\hline Other Patents (t-1) & 0.417 & 0.565 & & 0.477 & 0.616 & \\
& $(1.272)$ & $(3.404)$ & & $(1.369)$ & $(3.658)$ & \\
Energy Patents(t) & -0.511 & -1.277 & 1.606 & -0.729 & -1.412 & 1.257 \\
& $(-0.171)$ & $(-0.560)$ & $(0.576)$ & $(-0.267)$ & $(-0.696)$ & $(0.484)$ \\
Sales (t-1) & 1.014 & 0.599 & 2.192 & 0.587 & 0.239 & 1.805 \\
& $(0.817)$ & $(0.538)$ & $(2.161)$ & $(0.461)$ & $(0.218)$ & $(1.867)$ \\
Capital(t) & 4.655 & 5.234 & 3.037 & 5.016 & 5.525 & 3.440 \\
& $(1.706)$ & $(2.175)$ & $(1.238)$ & $(1.767)$ & $(2.255)$ & $(1.344)$ \\
Debt(t) & -0.788 & -0.728 & -0.958 & -0.715 & -0.676 & -0.848 \\
& $(-0.973)$ & $(-0.917)$ & $(-0.946)$ & $(-0.870)$ & $(-0.846)$ & $(-0.816)$ \\
trend & & & & 0.578 & 0.331 & 1.458 \\
& & & & $(0.740)$ & $(0.738)$ & $(2.639)$ \\
Year Dummies & YES & YES & YES & NO & NO & NO \\
\hline N & 254 & 254 & 254 & 254 & 254 & 254 \\
r2 & 0.703 & 0.718 & 0.578 & 0.690 & 0.704 & 0.524 \\
p-value for Hansen's J & 0.194 & 0.208 & 0.380 & 0.168 & 0.109 & 0.029 \\
Kleibergen-Paap rk Wald F stat & 1.667 & 8.010 & 9.473 & 1.673 & 8.826 & 8.787 \\
underidentification test p-value & 0.255 & $1.1 \mathrm{E}-04$ & $6.0 \mathrm{E}-05$ & 0.280 & $9.1 \mathrm{E}-04$ & 0.001 \\
\hline \hline
\end{tabular}

NOTE: Dependent variable is Other Patents $(t)$. T-statistics presented under estimates. 1 \& 2 year lagged independent variables and 2-year lagged energy patents used as instruments for Other Patents $(t-1)$ and Energy Patents. Regressions run from 1973-1999, with lagged data back to 1970 used for instruments. Energy prices and lagged energy prices also used as instruments in (4)-(6). Other Patents(t-3) also used as an instrument in columns (2) and (5). 
Table 13 - Correlations Among Refinery Patent Types

A. Correlations with annual number of patents in each type, 1973-1999

\begin{tabular}{lrrrrrrr} 
& Refining & Chemistry & Wells & Other & Environment & $\begin{array}{c}\text { Coal } \\
\text { Fuels }\end{array}$ & $\begin{array}{c}\text { Alt } \\
\text { Energy }\end{array}$ \\
\hline Refining & 1 & & & & & & \\
Chemistry & 0.635 & 1 & & & & & \\
Wells & 0.676 & 0.831 & 1 & & & & \\
Other & 0.574 & 0.813 & 0.894 & 1 & & & \\
Environment & 0.746 & 0.781 & 0.689 & 0.640 & 1 & \\
Coal Fuels & 0.182 & 0.496 & 0.582 & 0.772 & 0.301 & 1 \\
Alt Energy & 0.243 & 0.662 & 0.583 & 0.744 & 0.376 & 0.850 & 1 \\
\hline
\end{tabular}

B. Correlations with annual percentage of patents in each type, 1973-1999

\begin{tabular}{|c|c|c|c|c|c|c|c|}
\hline & $\begin{array}{c}\% \\
\text { Refining } \\
\end{array}$ & $\begin{array}{c}\% \\
\text { Chemistry }\end{array}$ & $\%$ Wells & $\%$ Other & $\begin{array}{c}\% \\
\text { Environment }\end{array}$ & $\begin{array}{l}\text { \% Coal } \\
\text { Fuels }\end{array}$ & $\begin{array}{c}\text { \% Alt } \\
\text { Energy }\end{array}$ \\
\hline \% Refining & 1 & & & & & & \\
\hline$\%$ Chemistry & 0.154 & 1 & & & & & \\
\hline$\%$ Wells & -0.198 & -0.355 & 1 & & & & \\
\hline$\%$ Other & -0.513 & -0.805 & 0.128 & 1 & & & \\
\hline \% Environment & 0.312 & 0.423 & -0.069 & -0.615 & 1 & & \\
\hline$\%$ Coal Fuels & -0.703 & -0.543 & 0.046 & 0.595 & -0.451 & 1 & \\
\hline \% Alt Energy & -0.704 & -0.222 & -0.036 & 0.342 & -0.391 & 0.776 & 1 \\
\hline
\end{tabular}

C. Correlations with annual number of patents in each type, 1973-1987

\begin{tabular}{lrrrrrrr} 
& Refining & Chemistry & Wells & Other & Environment & $\begin{array}{c}\text { Coal } \\
\text { Fuels }\end{array}$ & $\begin{array}{c}\text { Alt } \\
\text { Energy }\end{array}$ \\
\hline Refining & 1 & & & & & & \\
Chemistry & 0.368 & 1 & & & & & \\
Wells & 0.388 & 0.583 & 1 & & & & \\
Other & 0.488 & 0.516 & 0.315 & 1 & & & \\
Environment & 0.161 & 0.603 & 0.301 & 0.350 & 1 & \\
Coal Fuels & 0.334 & 0.255 & 0.193 & 0.819 & 0.211 & 1 \\
Alt Energy & 0.380 & 0.646 & 0.296 & 0.757 & 0.418 & 0.747 & 1 \\
\hline
\end{tabular}

D. Correlations with annual percentage of patents in each type, 1973-1987

\begin{tabular}{|c|c|c|c|c|c|c|c|}
\hline & $\begin{array}{c}\% \\
\text { Refining }\end{array}$ & $\begin{array}{c}\% \\
\text { Chemistry }\end{array}$ & $\%$ Wells & $\%$ Other & $\begin{array}{c}\% \\
\text { Environment }\end{array}$ & $\begin{array}{l}\text { \% Coal } \\
\text { Fuels }\end{array}$ & $\begin{array}{c}\text { \% Alt } \\
\text { Energy }\end{array}$ \\
\hline \% Refining & 1 & & & & & & \\
\hline$\%$ Chemistry & -0.465 & 1 & & & & & \\
\hline$\%$ Wells & 0.337 & 0.033 & 1 & & & & \\
\hline$\%$ Other & 0.329 & -0.878 & -0.148 & 1 & & & \\
\hline \% Environment & -0.142 & 0.285 & 0.071 & -0.324 & 1 & & \\
\hline \% Coal Fuels & -0.391 & -0.420 & -0.562 & 0.257 & -0.302 & 1 & \\
\hline \% Alt Energy & -0.601 & 0.197 & -0.648 & -0.296 & -0.136 & 0.634 & 1 \\
\hline
\end{tabular}

Tables show the correlation between patents in each technology group. The top two panels include all refinery patents with application years between 1973-1999. The bottom two panels include all refinery patents with application years between 1973-1987. This covers the period of growth and reduction for alternative energy patents. 
Table 14 - Descriptive Data on Citations and Generality

\begin{tabular}{lccccc}
\hline \hline & \multicolumn{2}{c}{ citations } & \multicolumn{2}{c}{ generality } \\
& $\mathbf{N}$ & mean & std dev & mean & std dev \\
Alternative Energy & & & & & \\
$\quad$ Energy & 2,018 & 8.722 & 10.682 & 0.509 & 0.342 \\
$\quad$ Non-energy & 49,295 & 6.658 & 8.840 & 0.470 & 0.364 \\
& & & & & \\
Automotive & & & & & \\
$\quad$ Energy & 1,519 & 7.840 & 8.721 & 0.422 & 0.351 \\
$\quad$ Non-energy & 43,062 & 6.718 & 8.206 & 0.434 & 0.358 \\
& & & & & \\
Refineries & & & & & \\
$\quad$ Alternative energy & 302 & 7.805 & 6.662 & 0.631 & 0.298 \\
$\quad$ Coal-based fuels & 627 & 6.260 & 6.306 & 0.424 & 0.353 \\
$\quad$ Refining & 3,152 & 7.076 & 8.733 & 0.422 & 0.343 \\
$\quad$ Environmental & 995 & 7.513 & 9.023 & 0.483 & 0.354 \\
$\quad$ Chemistry & 7,442 & 7.606 & 12.303 & 0.529 & 0.357 \\
$\quad$ Wells & 2,362 & 6.738 & 7.132 & 0.410 & 0.352 \\
$\quad$ Other Technologies & 9,778 & 5.741 & 7.408 & 0.437 & 0.370 \\
\hline \hline Descriptive data on patents from 1975-1999. & & & \\
\hline
\end{tabular}

Descriptive data on patents from 1975-1999. 
Table 15 - Are Alternative Energy Patents More Valuable?

\begin{tabular}{lrr} 
A. All Patents & & \\
\hline \hline Variable & Citations & Generality \\
\hline Alternative Energy patent & 1.1548 & 0.0595 \\
& $(5.735)$ & $(3.858)$ \\
Automotive Energy Patent & 1.5260 & 0.0987 \\
& $(15.209)$ & $(5.473)$ \\
Alternative Energy firm & 1.8813 & 0.1471 \\
& $(3.901)$ & $(1.415)$ \\
Chemistry patent & 0.9413 & 0.0376 \\
& $(-4.905)$ & $(4.824)$ \\
Computer patent & 1.3542 & 0.1455 \\
& $(19.039)$ & $(14.400)$ \\
Medical patent & 0.7708 & -0.1167 \\
& $(-5.441)$ & $(-3.844)$ \\
Electronics patent & 1.0503 & -0.0255 \\
& $(3.742)$ & $(-3.072)$ \\
Mechanical patent & 0.9647 & -0.0606 \\
& $(-2.997)$ & $(-7.992)$ \\
\hline$\Sigma$ & & 0.5958 \\
& & $(273.622)$ \\
\hline \multirow{2}{*}{ log-likelihood } & 90,288 & 90,288 \\
\hline \hline
\end{tabular}

B. Refinery Patents Only

\begin{tabular}{lrr}
\hline \hline Variable & Citations & Generality \\
Alternative Energy patent & 1.0711 & 0.2551 \\
& $(1.349)$ & $(6.591)$ \\
Coal-based Fuel patent & 0.8284 & -0.0366 \\
& $(-4.177)$ & $(-1.250)$ \\
Chemistry patent & 1.1239 & 0.1279 \\
& $(5.130)$ & $(8.959)$ \\
Wells patent & 1.0329 & -0.0270 \\
& $(1.162)$ & $(-1.468)$ \\
Environment patent & 1.1043 & 0.0715 \\
& $(2.640)$ & $(2.986)$ \\
Other patent & 0.8555 & -0.0182 \\
& $(-7.177)$ & $(-1.300)$ \\
\hline$\Sigma$ & & 0.6123 \\
& & $(142.528)$ \\
\hline \multirow{2}{*}{ log-likelihood } & 24,658 & 24,658 \\
\hline \hline
\end{tabular}

NOTES: T-statistics in parentheses. Generality results from a Tobit regression, and citation results from a general negative binomial regression. Citation results presented as $e^{\beta}$, and are interpreted as the likelihood of receiving a citation, compared to the base case of a non-energy automotive patent in panel A, or a refining patent in panel $\mathrm{B}$. 


\section{Figure 1 - Energy R\&D Spending}

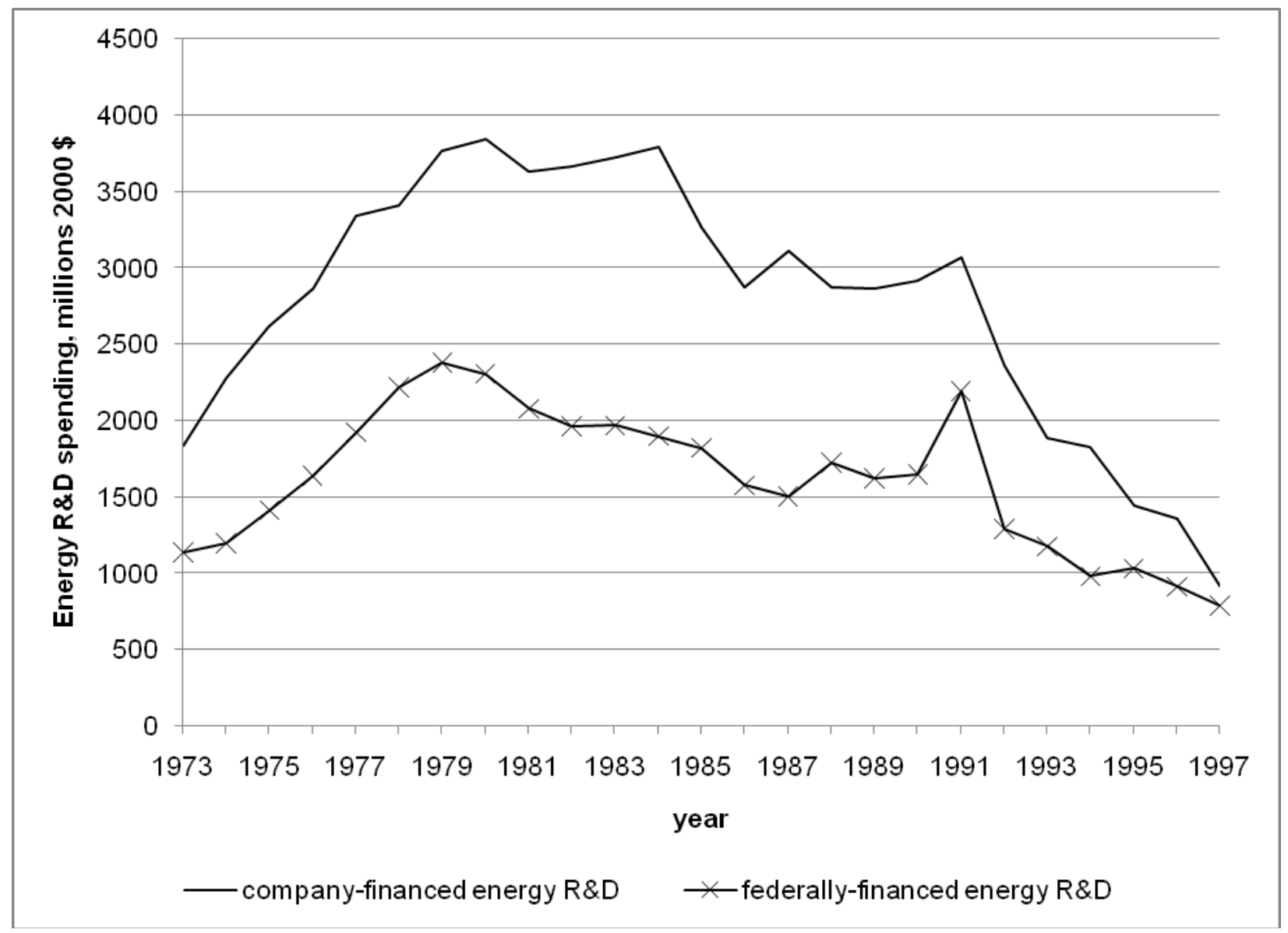

The figure shows company-financed and federal-government financed energy R\&D performed by industry from 1973-1997. All values are in 2000 dollars. 
Figure 2 - Total Alternative Energy Patents from All Energy Firms, by Application Year

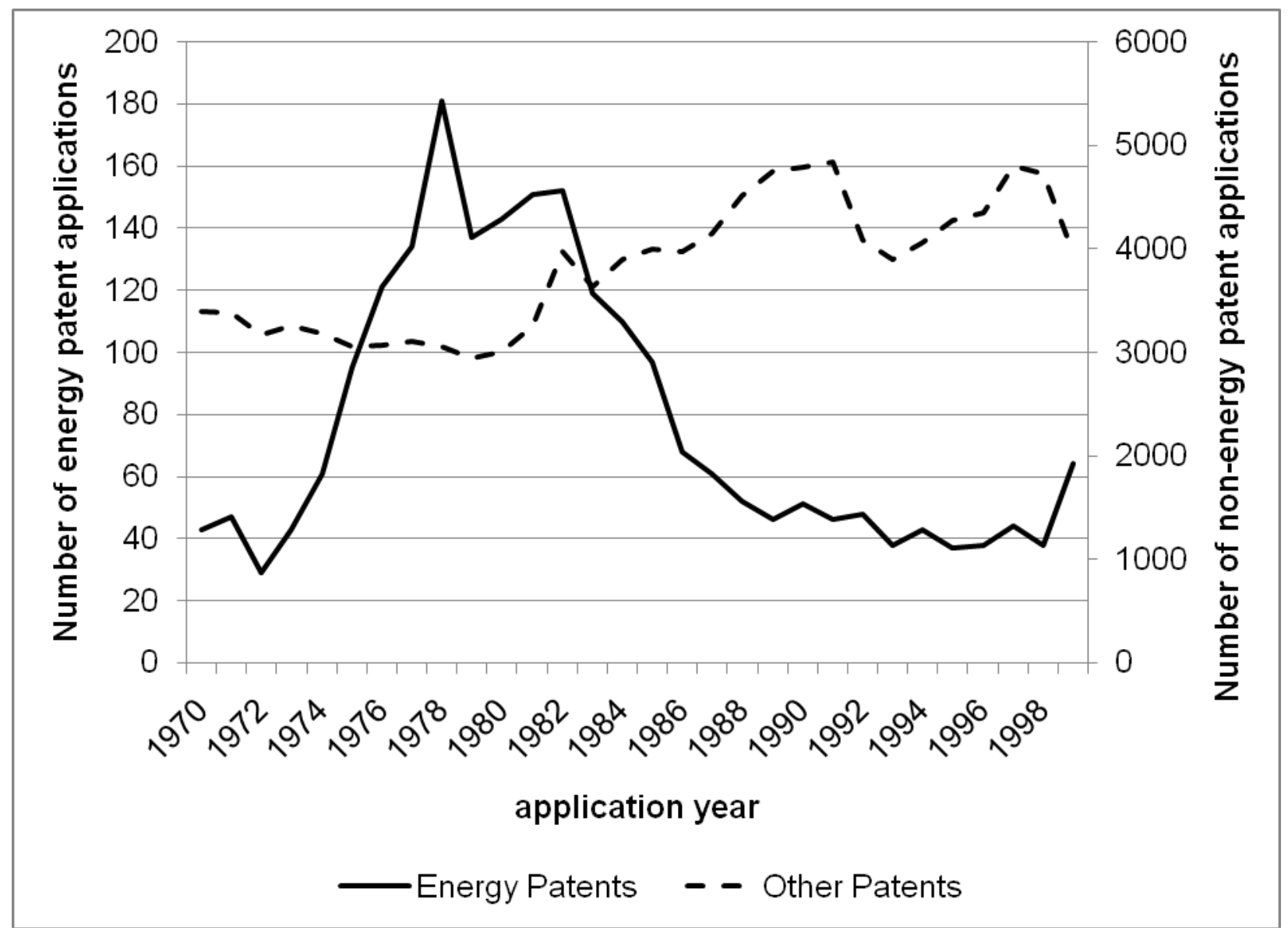

The figure shows the total number of alternative energy patents and non-energy patents assigned to firms in our regression analysis. The number of energy patents is on the left axis, and number of other and related patents is on the right axis. Patents are sorted by the year of application. 
Figure 3 - Total Automotive Energy Patents from All Energy Firms, by Application Year

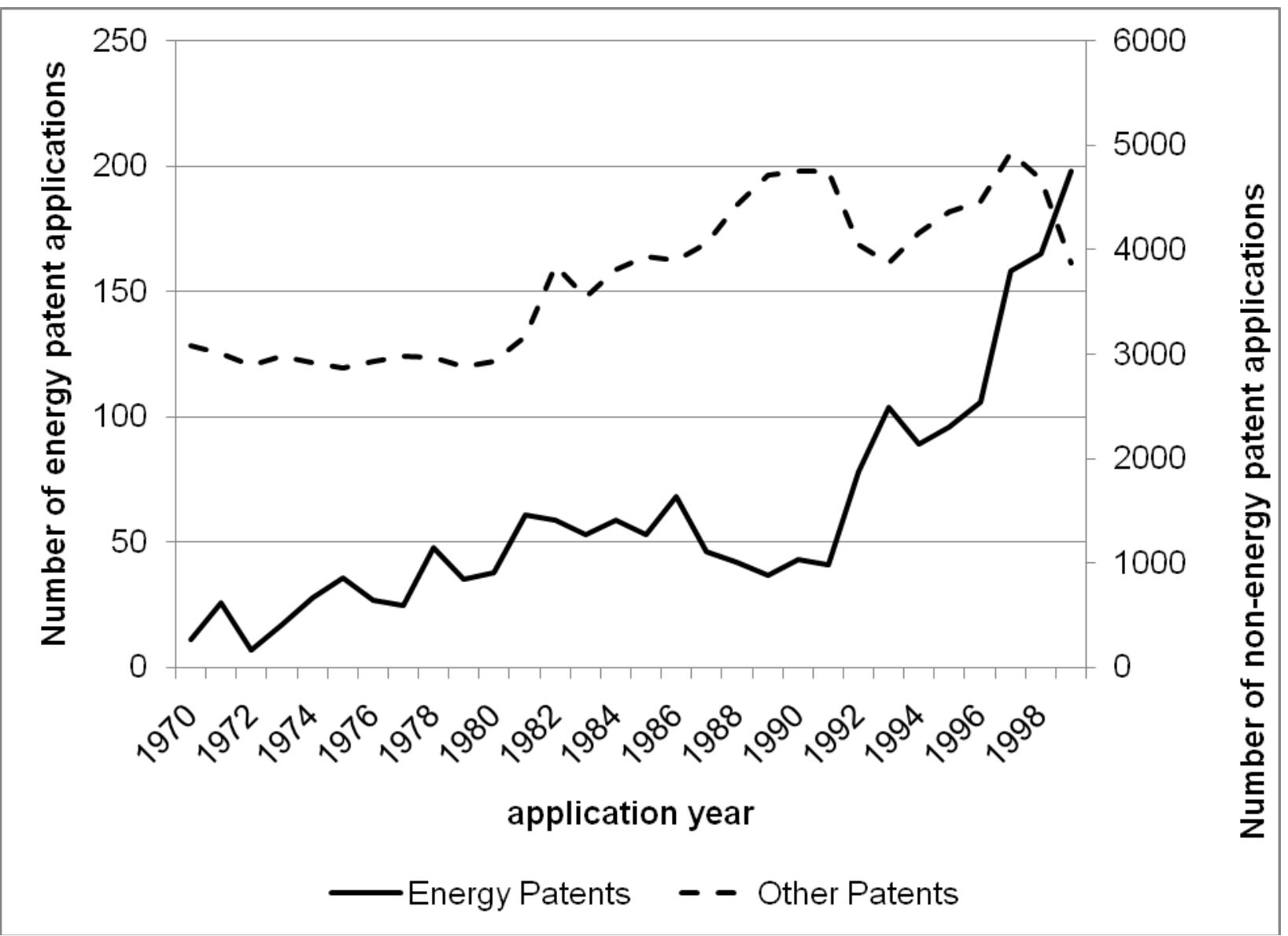

The figure shows the total number of energy patents and non-energy patents assigned to firms in our automotive energy regression analysis. The number of energy patents is on the left axis, and number of other and related patents is on the right axis. Patents are sorted by the year of application. 


\section{Figure 4 - Trends in Refinery Patent Types}

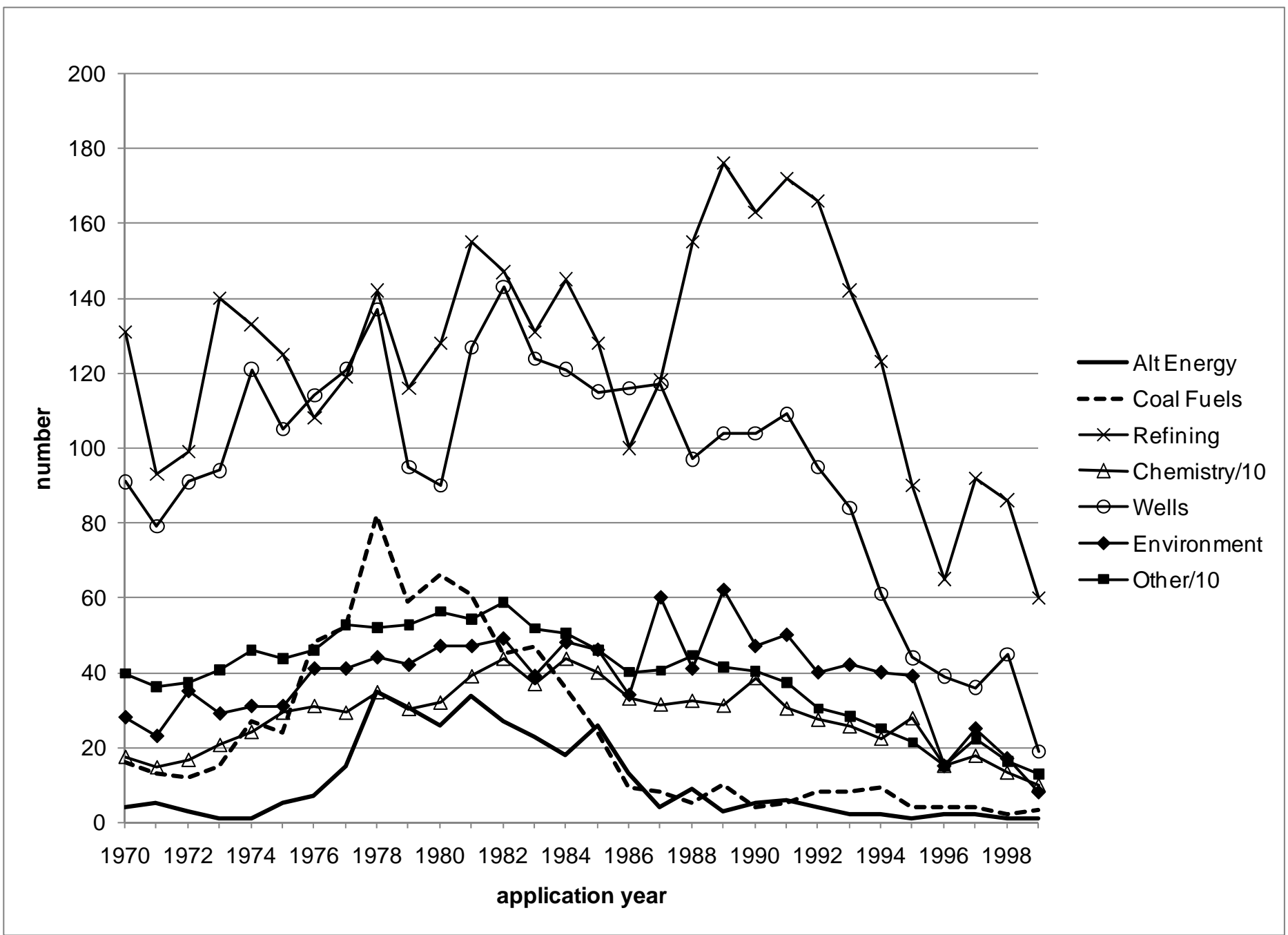

Figure includes refinery patents with application years between 1970-1999. The number of Chemistry and Other patents is divided by 10 for ease of presentation. 


\title{
Appendix A - Patent Classes for Energy Patents
}

NOTE: Patent classes for the alternative energy data set are based on the U.S. patent classification system. Patent classes for the automotive energy data set are based on the International Patent Classification system (IPC).

\author{
Alternative Energy \\ Coal Liquefaction: \\ 208/400-435 \\ Mineral Oils: Processes and Products/By treatment of solid material (e.g. \\ coal liquefaction) \\ Coal Gasification: \\ $48 / 200$ \\ $48 / 201$ \\ $48 / 202$ \\ $48 / 210$ \\ $48 / 71$ \\ $48 / 72$ \\ $48 / 73$ \\ $48 / 77$ \\ $48 / 98$ \\ $48 / 99$ \\ $48 / 100$ \\ $48 / 101$ \\ Gas: Heating and Illuminating/Processes/Coal, oil and water \\ Gas: Heating and Illuminating/Processes/Coal and oil \\ Gas: Heating and Illuminating/Processes/Coal and water \\ Gas: Heating and Illuminating/Processes/Coal \\ Gas: Heating and Illuminating/Generators/Cupola/Coal, oil and water \\ Gas: Heating and Illuminating/Generators/Cupola/Coal and oil \\ Gas: Heating and Illuminating/Generators/Cupola/Coal and water \\ Gas: Heating and Illuminating/Generators/Cupola/Producers/Coal \\ Gas: Heating and Illuminating/Generators/Retort/Coal, oil and water \\ Gas: Heating and Illuminating/Generators/Retort/Coal and water \\ Gas: Heating and Illuminating/Generators/Retort/Coal and oil \\ Gas: Heating and Illuminating/Generators/Retort/Coal
}

Solar Energy:

60/641.8-641.15

$62 / 235.1$

$126 / 561-568$

$126 / 569-713$

$126 / 903$

$126 / 904$

$126 / 905$

$126 / 906$

$126 / 910$
Power Plants/Utilizing natural heat/Solar

Refrigeration/Utilizing solar energy

Stoves and Furnaces/Solar heat collector for pond or pool

Stoves and Furnaces/Solar heat collector

Stoves and Furnaces/Cross-Reference Art/Solar collector cleaning device

Stoves and Furnaces/Cross-Reference Art/Arrangements for sealing solar

collector

Stoves and Furnaces/Cross-Reference Art/Preventing condensing of moisture in solar collector

Stoves and Furnaces/Cross-Reference Art/Connecting plural solar collectors in a circuit

Stoves and Furnaces/Cross-Reference Art/Heat storage liquid

Solar Energy - Batteries:

$136 / 206$

$136 / 243$

$136 / 244-251$

$136 / 252-265$
Batteries: Thermoelectric and Photoelectric/Thermoelectric/Electric power generator/ Solar energy type

Batteries: Thermoelectric and Photoelectric/Photoelectric

Batteries: Thermoelectric and Photoelectric/Photoelectric/Panel

Batteries: Thermoelectric and Photoelectric/Photoelectric/Cells 
Fuel Cells:

429/12-46

Chemistry: Electrical Current Producing Apparatus, Product, and

Process/Fuel cell, subcombination thereof or method of operating

Wind:

290/44

290/55

Prime-Mover Dynamo Plants/Electric control/Fluid-current motors/Wind

416/132B

Prime-Mover Dynamo Plants/Fluid-current motors/Wind

Fluid Reaction Surfaces (i.e., Impellers)/Articulated resiliently mounted or selfshifting impeller or working member/Sectional, staged or non-rigid working member/windmills

416/196A Fluid Reaction Surfaces (i.e., Impellers)/Lashing between working members or external bracing/Connecting adjacent work surfaces/Nonturbo machine (windmills)

416/197A

Fluid Reaction Surfaces (i.e., Impellers)/Cupped reaction surface normal to rotation plane/Air and water motors (natural fluid currents)

Using waste as fuel:

110/235-259

Furnaces/Refuse incinerator

$110 / 346$

Furnaces/Incinerating refuse

Geothermal energy:

60/641.2 -641.5 Power Plants/Utilizing Natural Heat/Geothermal 


\begin{abstract}
Automobiles
Energy efficiency:

$(((($ fuel OR gas*) $<$ near/1 $>$ (consum* OR use OR using OR usage OR burn*)) $<$ near/3> (reduc* OR less OR lower)) <in> (AB, TI, BACKGROUND)) OR (((fuel OR gas*) $<$ near/1> (efficien* OR economy OR mileage)) $<$ near/3> (improv* OR increas* OR better OR greater) $<$ in $>(A B, T I$, BACKGROUND)) $)$ AND (internal combustion $<$ in $>$ (AB, TI, BACKGROUND))
\end{abstract}

Fuel cells: H01M 8

PROCESSES OR MEANS, e.g. BATTERIES, FOR THE DIRECT CONVERSION OF CHEMICAL ENERGY INTO ELECTRICAL ENERGY /Fuel cells; Manufacture thereof

Electric \& hybrid vehicles:

B60W 20

CONJOINT CONTROL OF VEHICLE SUB-UNITS OF DIFFERENT

TYPE OR DIFFERENT FUNCTION; CONTROL SYSTEMS

SPECIALLY ADAPTED FOR HYBRID VEHICLES; ROAD VEHICLE DRIVE CONTROL SYSTEMS FOR PURPOSES NOT RELATED TO

THE CONTROL OF A PARTICULAR SUB-UNIT /Control systems specially adapted for hybrid vehicles, i.e. vehicles having two or more prime movers of more than one type, e.g. electrical and internal combustion motors, all used for propulsion of the vehicle

B60L 7 NOT B60L 7/28 ELECTRIC EQUIPMENT OR PROPULSION OF

ELECTRICALLY-PROPELLED VEHICLES; MAGNETIC SUSPENSION OR LEVITATION FOR VEHICLES; ELECTRODYNAMIC BRAKE SYSTEMS FOR VEHICLES, IN GENERAL/ Electrodynamic brake systems for vehicles in general

B60L 8 ELECTRIC EQUIPMENT OR PROPULSION OF ELECTRICALLYPROPELLED VEHICLES; MAGNETIC SUSPENSION OR LEVITATION FOR VEHICLES; ELECTRODYNAMIC BRAKE SYSTEMS FOR VEHICLES, IN GENERAL/ Electric propulsion with power supply from force of nature, e.g. sun, wind

B60L 11 ELECTRIC EQUIPMENT OR PROPULSION OF ELECTRICALLYPROPELLED VEHICLES; MAGNETIC SUSPENSION OR LEVITATION FOR VEHICLES; ELECTRODYNAMIC BRAKE SYSTEMS FOR VEHICLES, IN GENERAL/ Electric propulsion with power supplied within the vehicle 


\section{Appendix B - Patent Classes for Refineries}

In addition to the alternative energy patent classes in Appendix A, the following patent classes are used to categorize remaining patents by their intended use.

\section{Refining technologies}

Refining:

208/088-091

208/097-099

208/177-307

Catalytic cracking

208/108-112

208/113-124

Alkylation

585/446-468

$585 / 709-732$
Mineral Oils: Processes and Products/Chemical Conversion of Hydrocarbons/With preliminary treatment of feed/Refining Mineral Oils: Processes and Products/Chemical Conversion of Hydrocarbons/With subsequent treatment of products/Refining Mineral Oils: Processes and Products/Refining (except where noted below under environmental classes)

Mineral Oils: Processes and Products/Chemical Conversion of Hydrocarbons/Cracking/Hydrogenative/Catalytic Mineral Oils: Processes and Products/Chemical Conversion of Hydrocarbons/Cracking/Catalytic

Chemistry of Hydrocarbon Compounds/Aromatic Compound Synthesis/By condensation of entire molecules or entire hydrocarbyl moieties thereof, e.g., alkylation, etc/Using metal, metal oxide, or hydroxide catalyst

Chemistry of Hydrocarbon Compounds/Saturated Compound Synthesis/By condensation of a paraffin molecule with an olefin-acting molecule, e.g., alkylation, etc.

Catalytic Reforming: 208/134-141

Mineral Oils: Processes and Products/Chemical Conversion of Hydrocarbons/Reforming/Catalytic

Chemical conversion of hydrocarbons:

208/046-176

Mineral Oils: Processes and Products/Chemical Conversion of Hydrocarbons (except where mentioned elsewhere) 
Wells/Drilling

Wells/Drilling

166

Wells

405

Hydraulic and Earth Engineering

507

Earth Boring, Well Treating, and Oil Field Chemistry (except where noted below)

Enhanced oil recovery

507/935-938

Earth Boring, Well Treating, and Oil Field Chemistry/Enhanced Oil Recovery

\section{Chemistry}

Catalysts

502

Catalyst, Solid Sorbent, or Support Therefor: Product or Process of Making

Compositions/Products/Chemistry

252

423

428

Compositions

Chemistry of Inorganic Compounds

520-528

Stock Material or Miscellaneous Articles

585

Synthetic Resins or Natural Rubbers -- Part of the Class 520 Series

Chemistry of Hydrocarbon Compounds (if not included elsewhere) 


\section{Environmental}

Isomerization

$585 / 253$

$585 / 477-482$

$585 / 664-670$

$585 / 671$

$585 / 734-752$
Chemistry of Hydrocarbon Compounds/Adding Hydrogen to Unsaturated Bond of Hydrocarbon, i.e., Hydrogenation/With subsequent diverse conversion/Isomerization

Chemistry of Hydrocarbon Compounds/Aromatic Compound Synthesis/By isomerization

Chemistry of Hydrocarbon Compounds/Unsaturated Compound Synthesis/By double-bond shift isomerization Chemistry of Hydrocarbon Compounds/Unsaturated Compound Synthesis/By skeletal isomerization Chemistry of Hydrocarbon Compounds/Saturated Compound Synthesis/By isomerization

Carbon sequestration/removal

166/402-403

Wells/Processes/Distinct, separate injection and producing wells/Sequentially injected separate fluids (e.g., slugs)/Injecting a gas or gas mixture/CO2 or carbonated gas

Reformulated gas/adding ethers, MTBE, etc.

$44 / 438$

$44 / 446$

$44 / 447-449$

$44 / 451-453$

$568 / 692-699$
Fuel and Related Compositions/Organic oxygen compound containing (e.g. , alicyclic alcohols, hypochorites, etc.)/The oxygen is part of a $\mathrm{C}(=\mathrm{O})$ - group/With alkanol or dialkyl ether Fuel and Related Compositions/Organic oxygen compound containing (e.g. , alicyclic alcohols, hypochorites, etc.)/Alkanol compound with diaklyl ether compound Fuel and Related Compositions/Organic oxygen compound containing (e.g. , alicyclic alcohols, hypochorites, etc.)/Ether Fuel and Related Compositions/Organic oxygen compound containing (e.g. , alicyclic alcohols, hypochorites, etc.)/Alkanol Organic Compounds - Part of the 532-570 Series/Oxygen Containing (e.g., Perchlorylbenzene, etc.)/Ethers/Acyclic/Preparing by dehydrohalogenaition [This is 692. Others also are variants of processes using hydration)

Removal of gases (e.g. $\mathrm{SO}_{2}, \mathrm{NO}_{X}$, hydrogen sulfides)

423/210-248 Chemistry of Inorganic Compounds/Modifying or Removing Component of Normally Gaseous Mixture

423/569-577 Chemistry of Inorganic Compounds/Sulfur or Compound Thereof/Reducing sulfur dioxide by carbon containing material

Emissions control

422/168-183

Chemical Apparatus and Process: Disinfecting, Deodorizing, Preserving, or Sterilizing/Chemical Reactor/Waste gas purifier 
Cleaning spills

405/60-72 Hydraulic and Earth Engineering/Fluid Control, Treatment, or Containment/Floatable Matter Containment

210/671 Liquid Purification or Separation/Processes/Ion exchange or selective sorption/Including diverse separating or treating of liquid/Of oil sorbent material

210/680 Liquid Purification or Separation/Processes/Ion exchange or selective sorption/Utilizing exchange or sorbent material associated with inert material/Including oil sorbent

210/693 Liquid Purification or Separation/Processes/Ion exchange or selective sorption/Sorbing organic constituent/From aqueous material/Utilizing synthetic resin/Oil removed

210/776 Liquid Purification or Separation/Processes/Separating/Skimming

210/242.3 Liquid Purification or Separation/With Movable Support/Float/With oil water skimmer

210/242.4 Liquid Purification or Separation/With Movable Support/Float/With oil water sorption means

210/922-925 Liquid Purification or Separation/Cross-Reference Art Collections: Miscellaneous Specific Techniques/Oil spill cleanup (e.g., bacterial, etc.)

\section{Water Pollution}

Rather than using patent classes to identify these patents, the following keyword search of patent abstracts was used:

(water $<$ near/5 $>$ (pollut* OR effluent)) OR (waste $<$ near/1 $>$ water) OR (ground $<$ near $/ 1>$ water) OR wastewater OR groundwater 